\title{
New Abietane and Kaurane Type Diterpenoids from the Stems of Tripterygium regelii
}

\author{
Dongsheng Fan ${ }^{1}$, Shuangyan Zhou ${ }^{2}$, Zhiyuan Zheng ${ }^{1}$, Guo-Yuan Zhu ${ }^{1}$, Xiaojun Yao ${ }^{1,2}$, \\ Ming-Rong Yang ${ }^{1}$, Zhi-Hong Jiang ${ }^{1}$ and Li-Ping Bai ${ }^{1, *}$ \\ 1 State Key Laboratory of Quality Research in Chinese Medicine, Macau Institute for Applied Research in \\ Medicine and Health, Macau University of Science and Technology, Taipa, Macau 999078, China; \\ fandongsheng1985@sina.com (D.F.); zyzheng@must.edu.mo (Z.Z.); gyzhu@must.edu.mo (G.-Y.Z.); \\ xjyao@must.edu.mo (X.Y.); mryang@must.edu.mo (M.-R.Y.); zhjiang@must.edu.mo (Z.-H.J.) \\ 2 State Key Laboratory of Applied Organic Chemistry and Department of Chemistry, Lanzhou University, \\ Lanzhou 730000, China; zhoushy13@lzu.edu.cn \\ * Correspondence: lpbai@must.edu.mo; Tel.: +853-8897-2403; Fax: +853-2888-0091
}

Academic Editor: Jianhua Zhu

Received: 10 December 2016; Accepted: 6 January 2017; Published: 13 January 2017

\begin{abstract}
Eleven new abietane type (1-11), and one new kaurane (12), diterpenes, together with eleven known compounds (13-23), were isolated and identified from the stems of Tripterygium regelii, which has been used as a traditional folk Chinese medicine for the treatment of rheumatoid arthritis in China. The structures of new compounds were characterized by means of the interpretation of high-resolution electrospray ionization mass spectrometry (HRESIMS), extensive nuclear magnetic resonance (NMR) spectroscopic data and comparisons of their experimental CD spectra with calculated electronic circular dichroism (ECD) spectra. Compound $\mathbf{1}$ is the first abietane type diterpene with an $18 \rightarrow \mathbf{1}$ lactone ring. Compound 19 was isolated from the plants of the Tripterygium genus for the first time, and compounds 14-17 were isolated from T. regelii for the first time. Triregelin I (9) showed significant cytotoxicity against $\mathrm{A} 2780$ and HepG2 with $\mathrm{IC}_{50}$ values of 5.88 and $11.74 \mu \mathrm{M}$, respectively. It was found that this compound was inactive against MCF-7 cells. The discovery of these twelve new diterpenes not only provided information on chemical substances of T. regelii, but also contributed to the chemical diversity of natural terpenoids.
\end{abstract}

Keywords: Tripterygium regelii; diterpenoids; cytotoxicity

\section{Introduction}

Diterpenes are naturally-occurring 20-carbon terpenoids that display a wide array of potentially useful biological effects. Abietanes are a large group of diterpenoids, which have been isolated from a variety of terrestrial plants, such as families of Araucariaceae, Cupressaceae, Phyllocladaceae, Pinaceae, Podocarpaceae, Asteraceae, Celastraceae, Hydrocharitaceae, and Lamiaceae, etc. [1,2]. Furthermore, this class of diterpenes have been found from fungal species [2]. So far, it has been reported that some abietane type diterpenes displayed a broad spectrum of promising biological activities including anticancer [3], cytotoxic [4,5], antiviral [6-9], anti-inflammatory [10], and anti-oxidant [9] effects, and so on. For example, tanshinone IIA was regarded as a potent cytotoxic compound for human leukemia cells [11]. Carnosol has been found to possess favorable anticancer and chemo-preventive effects [12]. Triptolide is a promising lead compound to treat inflammatory, immunological and cancerous diseases [13]. Recently, it was reported that miltirone is an inhibitor of P-glycoprotein [14].

As a part of ongoing research work on bioactive constituents from Tripterygium regelii [15-17], the methanolic extract of the stems of T. regelii was further investigated, leading to the isolation and characterization of twenty three diterpenoids, including eleven new abietane (1-11) and one new 
kaurane type (12) diterpenes, as well as eleven known abietane compounds (13-23) (Figure 1). Herein, this paper reports the isolation and structural elucidation of these new diterpenes, as well as cytotoxic evaluation of seventeen diterpenes on three cancer cell lines.

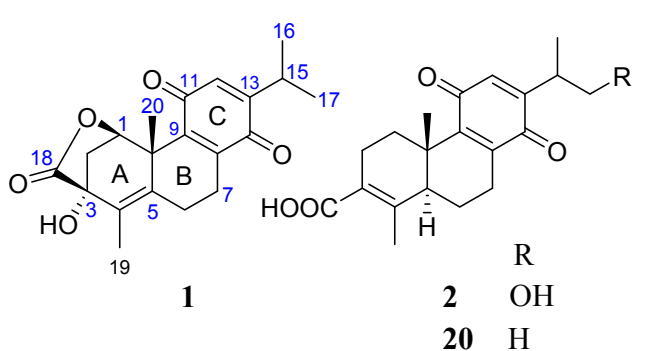

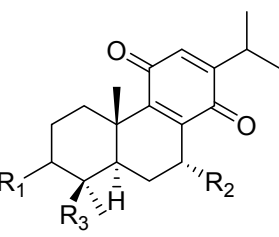

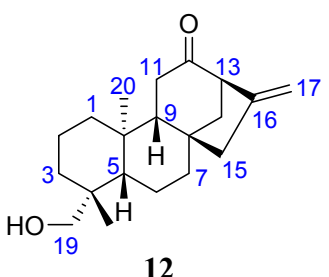<smiles>C=C1[C@H](CO)CC[C@]2(C)c3ccc(C(C)C)c(O)c3CC[C@H]12</smiles>

6<smiles>COc1cc2c(c(O)c1C(C)C)C=CC1[C@]([13CH3])(CO)C(=O)CC[C@]21C</smiles>

7

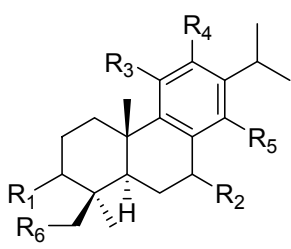

$\begin{array}{lllllll} & \mathrm{R}_{1} & \mathrm{R}_{2} & \mathrm{R}_{3} & \mathrm{R}_{4} & \mathrm{R}_{5} & \mathrm{R}_{6} \\ \mathbf{8} & =\mathrm{O} & =\mathrm{O} & \mathrm{OH} & \mathrm{H} & \mathrm{OH} & \mathrm{OH} \\ \mathbf{9} & \beta-\mathrm{OH} & =\mathrm{O} & \mathrm{OH} & \mathrm{H} & \mathrm{OH} & \mathrm{OH} \\ \mathbf{1 0} & \beta-\mathrm{OH} & =\mathrm{O} & \mathrm{H} & \mathrm{H} & \mathrm{OH} & \mathrm{OH} \\ \mathbf{1 1} & a-\mathrm{OH} & \mathrm{H} & \mathrm{H} & \mathrm{OH} & \mathrm{OCH}_{3} & \mathrm{H} \\ \mathbf{1 3} & =\mathrm{O} & \mathrm{H} & \mathrm{H} & \mathrm{H} & \mathrm{OH} & \mathrm{OH} \\ \mathbf{1 4} & =\mathrm{O} & \mathrm{H} & \mathrm{H} & \mathrm{OH} & \mathrm{OCH}_{3} & \mathrm{H} \\ \mathbf{1 5} & =\mathrm{O} & \mathrm{H} & \mathrm{H} & \mathrm{OH} & \mathrm{H} & \mathrm{OH} \\ \mathbf{1 6} & =\mathrm{O} & \mathrm{H} & \mathrm{H} & \mathrm{OCH}_{3} & \mathrm{OH} & \mathrm{OH} \\ \mathbf{1 7} & \beta-\mathrm{OH} & \mathrm{H} & \mathrm{H} & \mathrm{H} & \mathrm{OH} & \mathrm{OH} \\ \mathbf{1 8} & \beta-\mathrm{OH} & \mathrm{H} & \mathrm{H} & \mathrm{H} & \mathrm{OH} & \mathrm{H} \\ \mathbf{1 9} & \mathrm{H} & \mathrm{H} & \mathrm{H} & \mathrm{H} & \mathrm{OH} & \mathrm{OH}\end{array}$

Figure 1. The chemical structures of compounds 1-23.

\section{Results and Discussion}

Compound $\mathbf{1}$ was obtained as a yellow amorphous powder with a molecular formula of $\mathrm{C}_{20} \mathrm{H}_{22} \mathrm{O}_{5}$, which was determined by a protonated molecular ion at $m / z 343.1546[\mathrm{M}+\mathrm{H}]^{+}$(calcd for $\mathrm{C}_{20} \mathrm{H}_{23} \mathrm{O}_{5}$, 343.1540) in its high-resolution electrospray ionization mass spectrometry (HRESIMS), indicating 10 degrees of unsaturation. IR spectrum of 1 showed a lactone carbonyl band at $1732 \mathrm{~cm}^{-1}$ and benzoquinone bands at 1680 and $1601 \mathrm{~cm}^{-1}$. The UV spectrum of 1 exhibited an absorption maximum at $260 \mathrm{~nm}$, which is characteristic of a $p$-benzoquinone. The ${ }^{1} \mathrm{H}$ nuclear magnetic resonance (NMR) spectroscopic data (Table 1$)$ exhibited the characteristic signals for a benzoquinone proton $\left(\delta_{\mathrm{H}} 6.41\right.$ $(1 \mathrm{H}, \mathrm{d}, J=1.2 \mathrm{~Hz}, \mathrm{H}-12))$, an oxygenated methine $\left(\delta_{\mathrm{H}} 5.86(1 \mathrm{H}, \mathrm{d}, J=6.0 \mathrm{~Hz}, \mathrm{H}-1)\right)$, an isopropyl moiety including a methine $\left(\delta_{\mathrm{H}} 3.00(1 \mathrm{H}\right.$, sept $\left.\mathrm{d}, J=6.6,1.2 \mathrm{~Hz}, \mathrm{H}-15)\right)$ and two secondary methyls $\left(\delta_{\mathrm{H}} 1.12\right.$ and 1.11 (each $3 \mathrm{H}, \mathrm{d}, J=6.6 \mathrm{~Hz}, \mathrm{H}_{3}-16$ and $\left.\mathrm{H}_{3}-17\right)$ ), and two tertiary methyls $\left(\delta_{\mathrm{H}} 1.85\right.$ and 1.54 (each $3 \mathrm{H}, \mathrm{s}, \mathrm{H}_{3}-19$ and $\left.\mathrm{H}_{3}-20\right)$ ). The ${ }^{13} \mathrm{C}$ NMR spectroscopic data (Table 2) displayed resonances for 20 carbons, which were confirmed by distortionless enhancement by polarization transfer (DEPT) and heteronuclear single quantum coherence (HSQC) experiments to be an ester carbonyl carbon $\left(\delta_{\mathrm{C}} 177.3\right)$, a trisubstituted $p$-benzoquinone $\left(\delta_{\mathrm{C}} 187.3\right.$ (C-11), 186.8 (C-14), 153.9 (C-13), $146.0(\mathrm{C}-8)$, 144.6 (C-9) and $131.6(\mathrm{C}-12))$, a tetrasubstituted double bond $\left(\delta_{\mathrm{C}} 132.6\right.$ (C-5) and $\left.130.2(\mathrm{C}-4)\right)$, two aliphatic quaternary carbons (including an oxygenated one), two methines (including an oxygenated 
one), three methylenes, and four methyl groups. These spectroscopic data (Tables 1 and 2) suggested that compound 1 is an abietane type diterpene with a $p$-benzoquinone C-ring [18,19], structurally similar to the known triptoquinone A (20) [18], an 18(4 $\rightarrow 3)$-abeo-abietane quinone type diterpene, except for the A-ring. The $\Delta^{4,5}$ double bond was inferred from the $\mathrm{HMBC}$ correlations from $\mathrm{H}_{2}-2, \mathrm{H}_{2}-6$ and $\mathrm{H}_{3}-19$ to $\mathrm{C}-4\left(\delta_{\mathrm{C}} 130.2\right)$, from $\mathrm{H}-7\left(\delta_{\mathrm{H}} 2.90\right), \mathrm{H}_{3}-19$ and $\mathrm{H}_{3}-20$ to $\mathrm{C}-5\left(\delta_{\mathrm{C}} 132.6\right)$. The oxygenated methine $\left(\delta_{\mathrm{H}} 5.86 ; \delta_{\mathrm{C}} 78.4\right)$ was assigned to $\mathrm{C}-1$ based on the HMBC correlations from H-1 proton $\left(\delta_{\mathrm{H}} 5.86\right)$ to $\mathrm{C}-2\left(\delta_{\mathrm{C}} 39.1\right), \mathrm{C}-3\left(\delta_{\mathrm{C}} 74.3\right), \mathrm{C}-5\left(\delta_{\mathrm{C}} 132.6\right), \mathrm{C}-9\left(\delta_{\mathrm{C}} 144.6\right), \mathrm{C}-10\left(\delta_{\mathrm{C}} 44.7\right)$, and C-20 $\left(\delta_{\mathrm{C}} 23.7\right)$. The key HMBC correlation from $\mathrm{H}-1\left(\delta_{\mathrm{H}} 5.86\right)$ to $\mathrm{C}-18\left(\delta_{\mathrm{C}} 177.3\right)$ suggested a lactone formed between $\mathrm{C}-1$ and $\mathrm{C}-18$, accounting for the remaining one degree of unsaturation. Hydroxylation of C-3 was inferred from the HMBC correlations from $\mathrm{H}-1\left(\delta_{\mathrm{H}} 5.86\right), \mathrm{H}_{2}-2\left(\delta_{\mathrm{H}} 2.36\right.$ and 1.96$)$ and $\mathrm{H}_{3}-19\left(\delta_{\mathrm{H}} 1.85\right)$ to $\mathrm{C}-3\left(\delta_{\mathrm{C}} 74.3\right)$. It was deduced that the proton at $\mathrm{C}-1$ and the hydroxyl group at $\mathrm{C}-3$ should be a cis relationship due to the lactone between $\mathrm{C}-1$ and $\mathrm{C}-3$. Therefore, the proposed structure of $\mathbf{1}$ was established as a lactone derivative of triptoquinone $\mathrm{A}$ bearing $5 S, 10 S$ absolute configuration by $\mathrm{X}$-ray crystallographic analysis [18] (Figure 2).

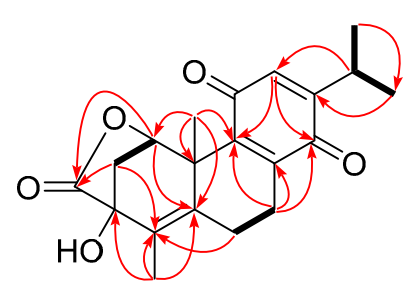

1

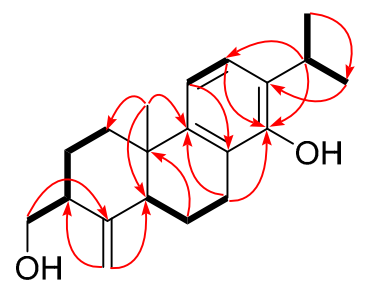

6

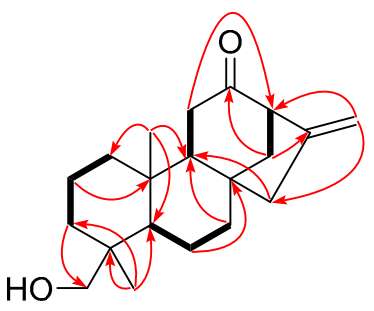

12

$$
{ }^{1} \mathrm{H}-{ }^{1} \mathrm{H} \operatorname{COSY} \longrightarrow \mathrm{HMBC} \frown
$$

Figure 2. The ${ }^{1} \mathrm{H}-{ }^{1} \mathrm{H}$ COSY and key HMBC correlations of compounds 1, 6, and 12.

However, the relative configuration of the substituents at the C- 1 and C-3 could not be assigned by nuclear Overhauser effect spectroscopy (NOESY) experiment, owing to the fact that no any key NOE effects were observed (Figure 3). Hence, electron circular dichroism (ECD) calculations were conducted to determine the absolute configuration of compound 1 by time-dependent density functional theory (TDDFT) with the B3LYP/DGDZVP method [20,21]. The calculated ECD of $(1 R, 3 R)-1$ matched well with the experimental CD spectrum (Figure $4 \mathrm{~A}$ ) of $\mathbf{1}$. Therefore, compound $\mathbf{1}$ was determined as proposed, and given the trivial name of triregelin A. 
Table 1. ${ }^{1} \mathrm{H}$ NMR (600 MHz) spectroscopic data for compounds $\mathbf{1 - 5}$ and 12.

\begin{tabular}{|c|c|c|c|c|c|c|}
\hline \multirow{2}{*}{ Position } & \multicolumn{6}{|c|}{$\delta_{\mathrm{H}}(J$ in $\mathrm{Hz})$} \\
\hline & $1^{a}$ & $2^{a}$ & $3^{a}$ & $4^{a}$ & $5^{a}$ & $12^{a}$ \\
\hline \multirow{2}{*}{1} & $5.86, \mathrm{~d}(6.0)$ & $1.45, \mathrm{~m}^{c}$ & 1.89, ddd $(14.4,10.2,5.4)$ & $1.90, \mathrm{~m}$ & $1.65, \mathrm{~m}$ & $0.79, \operatorname{td}(13.2,3.6)$ \\
\hline & - & $2.77, \mathrm{~m}^{c}$ & 2.80, ddd $(14.4,9.0,6.0)^{c}$ & $2.75, \mathrm{~m}^{\mathrm{c}}$ & $2.77, \mathrm{~m}^{c}$ & $1.79, \mathrm{~m}^{c}$ \\
\hline 2 & $2.36, \mathrm{~m}^{c}$ & $2.55, \mathrm{~m}$ & $2.73, \operatorname{ddd}(16.2,10.2,6.0)^{c}$ & $2.75, \mathrm{~m}^{c}$ & 3.03 , ddd $(15.6,7.2,3.6)^{c}$ & $1.55, \mathrm{~m}^{c}$ \\
\hline \multirow{2}{*}{3} & - & - & - & - & - & $0.95, \mathrm{dd}(13.8,4.2)$ \\
\hline & - & - & - & - & - & $1.79, \mathrm{~m}^{c}$ \\
\hline 6 & $2.76, \mathrm{dd}(13.2,6.0)$ & $2.24, \mathrm{~m}^{c}$ & 1.96, br d $(13.8)$ & 2.02, $\mathrm{dt}(13.8,1.8)$ & 1.96, br d, d $(13.2,7.2)$ & $1.72, \mathrm{~m}^{\mathrm{c}}$ \\
\hline \multirow{2}{*}{7} & $2.37, \mathrm{~m}^{c}$ & $2.39, \mathrm{ddd}(18.6,11.4,7.2)$ & $4.81, \mathrm{br} \mathrm{s}$ & $4.39, \mathrm{dd}(3.0,1.8)$ & $2.34, \operatorname{ddd}(18.6,12.0,7.2)$ & $1.62, \mathrm{dd}(13.8,4.8)$ \\
\hline & 2.90, dd $(19.8,6.0)$ & $2.80, \mathrm{~m}$ & - & - & $2.81, \mathrm{~m}^{\mathrm{c}}$ & $1.72, \mathrm{~m}^{\mathrm{c}}$ \\
\hline 9 & - & - & - & - & - & $1.58, \mathrm{~m}^{c}$ \\
\hline 11 & - & - & - & - & - & $2.24, \mathrm{~d}(17.0)$ \\
\hline 14 & - & - & - & - & - & $2.40, \mathrm{~d}(12.6)$ \\
\hline 15 & 3.00, sept d $(6.6,1.2)$ & $3.12, \mathrm{~m}$ & 3.02, sept $(7.0)$ & 3.04, sept d $(7.2,1.2)$ & $3.00, \mathrm{~d}(7.2)^{c}$ & $2.36, \mathrm{~s}$ \\
\hline 16 & $1.12, \mathrm{~d}(6.6)$ & $1.17, \mathrm{~d}(7.2)$ & $1.14, \mathrm{~d}(7.0)$ & $1.12, \mathrm{~d}(7.2)$ & $1.10, \mathrm{~d}(7.2)$ & - \\
\hline \multirow[b]{2}{*}{17} & $1.11, \mathrm{~d}(6.6)$ & $3.67, \mathrm{~d}(7.2)$ & $1.13, \mathrm{~d}(7.0)$ & $1.13, \mathrm{~d}(7.2)$ & $1.11, \mathrm{~d}(7.2)$ & $4.87, \mathrm{~s}$ \\
\hline & - & - & - & - & - & $4.99, \mathrm{~s}$ \\
\hline 18 & - & - & $1.37, \mathrm{~s}$ & $1.36, \mathrm{~s}$ & $1.22, \mathrm{~s}$ & $0.98, \mathrm{~s}$ \\
\hline \multirow[b]{2}{*}{19} & $1.85, \mathrm{~s}$ & $2.11, \mathrm{~s}$ & $3.47, \mathrm{t}(10.8)$ & $3.44, \mathrm{~d}(12.0)$ & $4.56, \mathrm{~d}(12.0)$ & $3.68, \mathrm{dd}(10.1,4.0)$ \\
\hline & $\begin{array}{l}1.00, \mathrm{~s} \\
-\end{array}$ & $\begin{array}{l}2.11, \mathrm{~S} \\
-\end{array}$ & $4.02, \mathrm{dd}(10.8,2.4)$ & $4.05, \mathrm{~d}(12.0)$ & $4.08, \mathrm{~d}(12.0)$ & 3.44 , dd $(10.1,4.0)$ \\
\hline 20 & $1.54, \mathrm{~s}$ & $1.18 \mathrm{~s}$ & $1.24 \mathrm{~s}$ & $1.22, \mathrm{~s}$ & $1.44, \mathrm{~s}$ & $0.85, \mathrm{~s}$ \\
\hline OH-7 & - & - & $2.77, \mathrm{~s}^{c}$ & - & - & - \\
\hline OH-19 & - & - & $3.15, \mathrm{dd}(10.8,2.4)$ & $3.26, \mathrm{br} \mathrm{s}$ & - & $1.09, \mathrm{br} \mathrm{s}$ \\
\hline OMe-7 & - & - & - & $3.50, \mathrm{~s}$ & - & - \\
\hline OAc-19 & - & - & - & - & $2.03, \mathrm{~s}$ & - \\
\hline
\end{tabular}

${ }^{a}$ Measured in $\mathrm{CDCl}_{3} ;{ }^{c}$ Overlapping signal was assigned from ${ }^{1} \mathrm{H}-{ }^{1} \mathrm{H}$ COSY, $\mathrm{HSQC}$ and $\mathrm{HMBC}$ experiments. The signals of br, $\mathrm{s}, \mathrm{d}, \mathrm{t}, \mathrm{q}$, sept and $\mathrm{m}$ represent broad, singlet, doublet, triplet, quartet, septet and multiplet splitting patterns of protons, respectively. 
Table 2. ${ }^{13} \mathrm{C}$ NMR (150 MHz) spectroscopic data for compounds 1-12.

\begin{tabular}{|c|c|c|c|c|c|c|c|c|c|c|c|c|}
\hline \multirow{2}{*}{ Position } & \multicolumn{12}{|c|}{$\delta_{\mathrm{C}}$, Type } \\
\hline & $1^{a}$ & $2^{a}$ & $3^{a}$ & $4^{a}$ & $5^{a}$ & $6^{a}$ & $7^{a}$ & $8^{a}$ & $9^{a}$ & $10^{a}$ & $11^{b}$ & $12^{a}$ \\
\hline 1 & $78.4, \mathrm{CH}$ & $31.8, \mathrm{CH}_{2}$ & $34.1, \mathrm{CH}_{2}$ & $34.1, \mathrm{CH}_{2}$ & $34.7, \mathrm{CH}_{2}$ & $38.2, \mathrm{CH}_{2}$ & $35.1, \mathrm{CH}_{2}$ & $35.1, \mathrm{CH}_{2}$ & $34.5, \mathrm{CH}_{2}$ & $36.2, \mathrm{CH}_{2}$ & $32.8, \mathrm{CH}_{2}$ & 39.7, $\mathrm{CH}_{2}$ \\
\hline 2 & $39.1, \mathrm{CH}_{2}$ & $24.6, \mathrm{CH}_{2}$ & $34.2, \mathrm{CH}_{2}$ & $34.2, \mathrm{CH}_{2}$ & $34.9, \mathrm{CH}_{2}$ & $27.4, \mathrm{CH}_{2}$ & $35.3, \mathrm{CH}_{2}$ & $34.8, \mathrm{CH}_{2}$ & $28.3, \mathrm{CH}_{2}$ & $28.1, \mathrm{CH}_{2}$ & $27.0, \mathrm{CH}_{2}$ & $17.8, \mathrm{CH}_{2}$ \\
\hline 3 & $74.3, \mathrm{C}$ & $147.9, \mathrm{C}$ & $220.4, C$ & $220.8, C$ & $212.4, C$ & $46.1, \mathrm{CH}$ & $214.8, C$ & $219.0, \mathrm{C}$ & $79.7, \mathrm{CH}$ & $79.9, \mathrm{CH}$ & $74.8, \mathrm{CH}$ & $35.5, \mathrm{CH}_{2}$ \\
\hline 4 & $130.2, \mathrm{C}$ & $124.5, \mathrm{C}$ & $49.9, \mathrm{C}$ & $49.7, \mathrm{C}$ & $51.3, \mathrm{C}$ & $150.8, \mathrm{C}$ & $53.0, \mathrm{C}$ & $50.3, \mathrm{C}$ & $42.8, \mathrm{C}$ & $42.3, \mathrm{C}$ & $38.3, \mathrm{C}$ & $38.6, \mathrm{C}$ \\
\hline 5 & $132.6, \mathrm{C}$ & $47.3, \mathrm{CH}$ & $45.2, \mathrm{CH}$ & $44.9, \mathrm{CH}$ & $52.9, \mathrm{CH}$ & $47.9, \mathrm{CH}$ & $51.5, \mathrm{CH}$ & $49.4, \mathrm{CH}$ & $49.6, \mathrm{CH}$ & $48.8, \mathrm{CH}$ & $44.0, \mathrm{CH}$ & $56.2, \mathrm{CH}$ \\
\hline 6 & $22.2, \mathrm{CH}_{2}$ & $18.7, \mathrm{CH}_{2}$ & 26.1, $\mathrm{CH}_{2}$ & $22.5, \mathrm{CH}_{2}$ & $18.5, \mathrm{CH}_{2}$ & $20.8, \mathrm{CH}_{2}$ & 124.0, $\mathrm{CH}$ & $35.6, \mathrm{CH}_{2}$ & $35.5, \mathrm{CH}_{2}$ & $35.7, \mathrm{CH}_{2}$ & $18.9, \mathrm{CH}_{2}$ & $20.2, \mathrm{CH}_{2}$ \\
\hline 7 & $27.0, \mathrm{CH}_{2}$ & $25.2, \mathrm{CH}_{2}$ & $61.9, \mathrm{CH}$ & $69.8, \mathrm{CH}$ & $26.0, \mathrm{CH}_{2}$ & $23.7, \mathrm{CH}_{2}$ & $122.1, \mathrm{CH}$ & $204.3, C$ & $205.6, C$ & $205.2, C$ & $25.1, \mathrm{CH}_{2}$ & $39.4, \mathrm{CH}_{2}$ \\
\hline 8 & $146.0, C^{2}$ & 142. $6, \mathrm{C}$ & $140.9, \mathrm{C}$ & $139.3, \mathrm{C}$ & $142.8, C^{2}$ & $120.7, \mathrm{C}$ & $113.6, \mathrm{C}$ & $114.9, \mathrm{C}$ & 115.1, C & $114.2, \mathrm{C}$ & $119.7, \mathrm{C}$ & $44.1, \mathrm{C}$ \\
\hline 9 & $144.6, \mathrm{C}$ & $149.0, \mathrm{C}$ & $148.7, \mathrm{C}$ & $148.6, \mathrm{C}$ & $148.0, \mathrm{C}$ & $145.8, \mathrm{C}$ & $145.2, \mathrm{C}$ & $133.1, \mathrm{C}$ & 134.7, C & $153.1, \mathrm{C}$ & $150.0, \mathrm{C}$ & $57.6, \mathrm{CH}$ \\
\hline 10 & $44.7, \mathrm{C}$ & $36.6, \mathrm{C}$ & $37.5, \mathrm{C}$ & $37.3, \mathrm{C}$ & $37.6, \mathrm{C}$ & $39.7, \mathrm{C}$ & $37.7, \mathrm{C}$ & $38.3, \mathrm{C}$ & $39.5, \mathrm{C}$ & $37.5, \mathrm{C}$ & $37.9, \mathrm{C}$ & $39.2, \mathrm{C}$ \\
\hline 11 & 187.3, C & 187.4, C & $187.8, \mathrm{C}$ & $187.9, \mathrm{C}$ & $187.5, \mathrm{C}$ & $117.6, \mathrm{CH}$ & $98.4, \mathrm{CH}$ & $144.5, \mathrm{C}$ & $144.2, \mathrm{C}$ & 113.6, CH & $108.8, \mathrm{CH}$ & $35.9, \mathrm{CH}_{2}$ \\
\hline 12 & 131.6, $\mathrm{CH}$ & 134.0, $\mathrm{CH}$ & 132.4, $\mathrm{CH}$ & $131.8, \mathrm{CH}$ & 132.0, $\mathrm{CH}$ & 123.3, $\mathrm{CH}$ & $158.3, \mathrm{C}$ & $123.8, \mathrm{CH}$ & 123.9, $\mathrm{CH}$ & 133.6, $\mathrm{CH}$ & $156.5, \mathrm{C}$ & $211.5, \mathrm{C}$ \\
\hline 13 & $153.9, \mathrm{C}$ & 149.0, C & 153.6, C & 154.0, C & $153.3, \mathrm{C}$ & $130.3, \mathrm{C}$ & $119.6, \mathrm{C}$ & $136.6, \mathrm{C}$ & $136.3, \mathrm{C}$ & $134.9, \mathrm{C}$ & $125.1, \mathrm{C}$ & $60.7, \mathrm{CH}$ \\
\hline 14 & $186.8, \mathrm{C}$ & $188.1, \mathrm{C}$ & $188.7, \mathrm{C}$ & $186.4, \mathrm{C}$ & $187.4, \mathrm{C}$ & $150.3, \mathrm{C}$ & $150.3, \mathrm{C}$ & $155.4, \mathrm{C}$ & $155.7, \mathrm{C}$ & $160.7, \mathrm{C}$ & $156.9, \mathrm{C}$ & $39.4, \mathrm{CH}_{2}$ \\
\hline 15 & $26.6, \mathrm{CH}$ & $34.5, \mathrm{CH}$ & $26.4, \mathrm{CH}$ & $26.5, \mathrm{CH}$ & $26.4, \mathrm{CH}$ & $26.9, \mathrm{CH}$ & $24.3, \mathrm{CH}$ & $26.0, \mathrm{CH}$ & $26.0, \mathrm{CH}$ & $26.1, \mathrm{CH}$ & $26.1, \mathrm{CH}$ & $48.2, \mathrm{CH}$ \\
\hline 16 & 21.3, $\mathrm{CH}_{3}$ & $15.4, \mathrm{CH}_{3}$ & $21.3, \mathrm{CH}_{3}$ & $21.3, \mathrm{CH}_{3}$ & $21.3, \mathrm{CH}_{3}$ & $22.6, \mathrm{CH}_{3}$ & $20.9, \mathrm{CH}_{3}$ & $22.1, \mathrm{CH}_{3}$ & $22.1, \mathrm{CH}_{3}$ & $22.1, \mathrm{CH}_{3}$ & $21.6, \mathrm{CH}_{3}$ & $148.8, \mathrm{C}$ \\
\hline 17 & $21.4, \mathrm{CH}_{3}$ & $66.6, \mathrm{CH}_{2}$ & $21.3, \mathrm{CH}_{3}$ & $21.4, \mathrm{CH}_{3}$ & $21.3, \mathrm{CH}_{3}$ & $22.8, \mathrm{CH}_{3}$ & $20.9, \mathrm{CH}_{3}$ & $22.2, \mathrm{CH}_{3}$ & $22.2, \mathrm{CH}_{3}$ & $22.3, \mathrm{CH}_{3}$ & $21.7, \mathrm{CH}_{3}$ & $107.8, \mathrm{CH}_{2}$ \\
\hline 18 & $177.3, \mathrm{C}$ & $173.7, \mathrm{C}$ & $22.3, \mathrm{CH}_{3}$ & $22.3, \mathrm{CH}_{3}$ & $21.8, \mathrm{CH}_{3}$ & 64.7, $\mathrm{CH}_{2}$ & $19.7, \mathrm{CH}_{3}$ & $22.6, \mathrm{CH}_{3}$ & $22.4, \mathrm{CH}_{3}$ & $22.0, \mathrm{CH}_{3}$ & $29.1, \mathrm{CH}_{3}$ & $26.9, \mathrm{CH}_{3}$ \\
\hline 19 & $11.8, \mathrm{CH}_{3}$ & $18.5, \mathrm{CH}_{3}$ & 65.7, $\mathrm{CH}_{2}$ & $65.8, \mathrm{CH}_{2}$ & 65.7, $\mathrm{CH}_{2}$ & $104.5, \mathrm{CH}_{2}$ & $65.9, \mathrm{CH}_{2}$ & $65.5, \mathrm{CH}_{2}$ & 63.7, $\mathrm{CH}_{2}$ & 63.7, $\mathrm{CH}_{2}$ & $22.4, \mathrm{CH}_{3}$ & $65.4, \mathrm{CH}_{2}$ \\
\hline 20 & 23.7, $\mathrm{CH}_{3}$ & $19.2, \mathrm{CH}_{3}$ & $19.7, \mathrm{CH}_{3}$ & $20.0, \mathrm{CH}_{3}$ & $20.2, \mathrm{CH}_{3}$ & $22.5, \mathrm{CH}_{3}$ & $20.3, \mathrm{CH}_{3}$ & $18.3, \mathrm{CH}_{3}$ & $18.3, \mathrm{CH}_{3}$ & $24.2, \mathrm{CH}_{3}$ & $25.2, \mathrm{CH}_{3}$ & $16.4, \mathrm{CH}_{3}$ \\
\hline OMe-7 & - & - & - & $57.9, \mathrm{CH}_{3}$ & - & - & - & - & - & - & - & - \\
\hline OMe-12 & - & - & - & - & - & - & $55.7, \mathrm{CH}_{3}$ & - & - & - & - & - \\
\hline OMe-14 & - & - & - & - & - & - & - & - & - & - & $60.5, \mathrm{CH}_{3}$ & - \\
\hline & - & - & - & - & $20.9, \mathrm{CH}_{3}$ & - & - & - & - & - & - & - \\
\hline ОАс-19 & - & - & - & - & $170.8, \mathrm{C}$ & - & - & - & - & - & - & - \\
\hline
\end{tabular}

${ }^{a}$ Measured in $\mathrm{CDCl}_{3} ;{ }^{b}$ Measured in pyridine- $d_{5}$. 

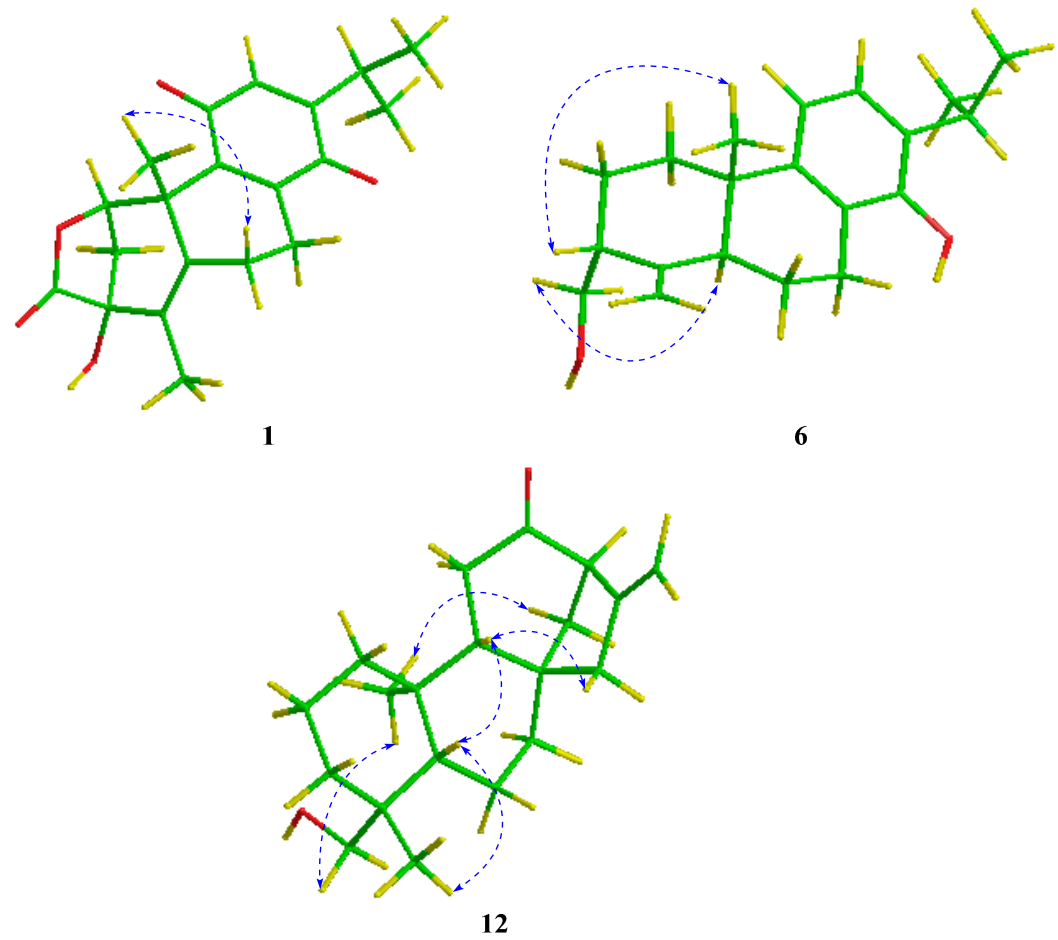

NOESY , , - . -

Figure 3. The selected NOESY correlations of compounds 1, 6, and 12. The red, yellow and green atoms represent oxygens, hydrogens and carbons, respectively.
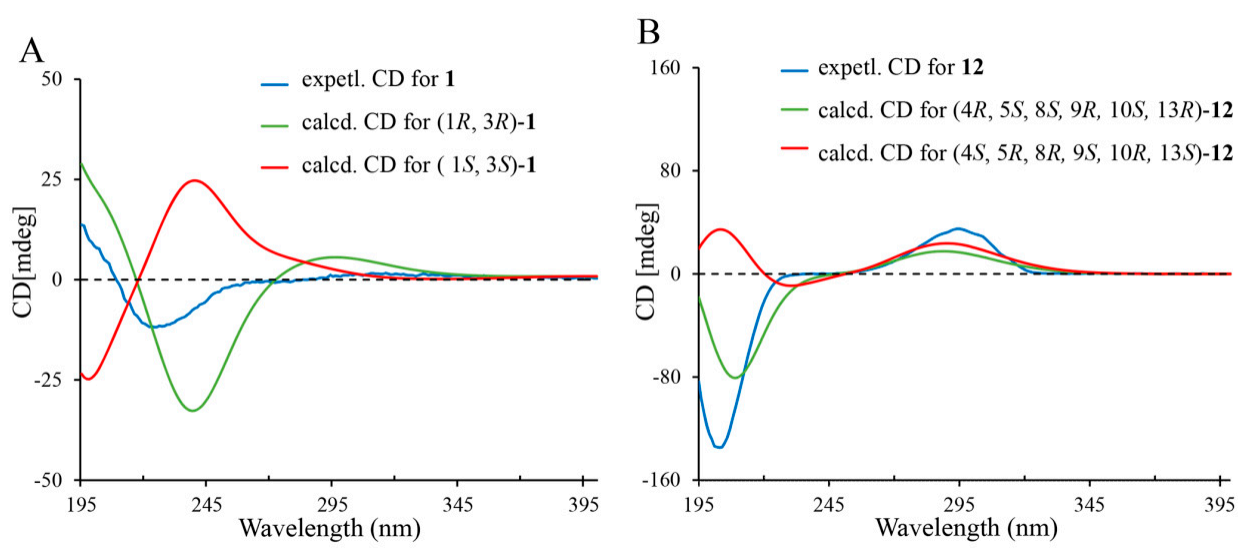

Figure 4. Experimental and calculated CD spectra of compounds $\mathbf{1}(\mathbf{A})$ and $12(\mathbf{B})$.

Compound 2 was assigned as a molecular formula of $\mathrm{C}_{20} \mathrm{H}_{24} \mathrm{O}_{5}$ based on a deprotonated molecular ion at $m / z 343.1560[\mathrm{M}-\mathrm{H}]^{-}$(calcd for $\mathrm{C}_{20} \mathrm{H}_{23} \mathrm{O}_{5}, 343.1551$ ) in its HRESIMS. IR spectrum of 2 exhibited a conjugated carboxylic acid band at $1688 \mathrm{~cm}^{-1}$ and benzoquinone band at $1649 \mathrm{~cm}^{-1}$. The ${ }^{1} \mathrm{H}$ and ${ }^{13} \mathrm{C}$ NMR spectroscopic data (Tables 1 and 2) of 2 were closely analogous to those of triptoquinone $\mathrm{A}(20)$ [18], except for the absence of a secondary methyl group and the presence of a hydroxymethyl group $\left(\delta_{\mathrm{H}} 3.67\left(2 \mathrm{H}, \mathrm{d}, J=7.2 \mathrm{~Hz}, \mathrm{H}_{2}-17\right) ; \delta_{\mathrm{C}} 66.6\right)$. The hydroxymethyl group was allocated to be at $\mathrm{C}-15$, as deduced by ${ }^{1} \mathrm{H}-{ }^{1} \mathrm{H}$ COSY correlation of $\mathrm{H}-15 / \mathrm{H}_{2}-17$ and $\mathrm{HMBC}$ correlations from the hydroxymethyl protons to $C-13\left(\delta_{C} 149.0\right)$ and $C-15\left(\delta_{C} 34.5\right)$. Therefore, compound 2 was characterized and given a trivial name of triregelin $\mathrm{B}$.

Compound 3 showed a molecular formula of $\mathrm{C}_{20} \mathrm{H}_{26} \mathrm{O}_{5}$, as established from an $[\mathrm{M}+\mathrm{H}]^{+}$ion at $m / z 347.1866$ (calcd $\mathrm{C}_{20} \mathrm{H}_{27} \mathrm{O}_{5}, 347.1853$ ) in the HRESIMS. Analysis of the NMR spectroscopic data 
(Tables 1 and 2) indicated that 3 was structurally related to triptoquinone B (21) [18] except for the absence of the $\mathrm{C}-7$ methylene in triptoquinone $\mathrm{B}$ and the presence of an additional hydroxyl proton $\left(\delta_{\mathrm{H}} 2.77\right)$ and an oxygenated methine $\left(\delta_{\mathrm{H}} 4.81, \delta_{\mathrm{C}} 61.9\right)$ in 3 . These data suggested hydroxylation of C-7 in 3, which was supported by HMBC correlation from the hydroxyl proton $\left(\delta_{\mathrm{H}} 2.77\right)$ to C-7 $\left(\delta_{C} 61.9\right)$. The $\alpha$-orientation of the hydroxyl group at $C-7$ was deduced from the NOESY correlation of $\mathrm{H}-7 / \mathrm{H}_{3}-20$. Thus, compound 3 was identified and named triregelin $\mathrm{C}$.

Compound 4 gave a molecular formula of $\mathrm{C}_{21} \mathrm{H}_{28} \mathrm{O}_{5}$, as deduced from an $[\mathrm{M}+\mathrm{H}]^{+}$ion at $\mathrm{m} / z$ 361.2008 (calcd $\mathrm{C}_{21} \mathrm{H}_{29} \mathrm{O}_{5}, 361.2010$ ), 14.0142 atomic mass units (amu) more than that of 3 in the HRESIMS. The ${ }^{1} \mathrm{H}$ and ${ }^{13} \mathrm{C}$ NMR spectroscopic data (Tables 1 and 2) of 4 were closely similar to those of 3, except for the appearance of a methoxyl group. The methoxyl group was assigned at C-7, as evidenced from the observed HMBC correlation from the methoxyl protons $\left(\delta_{\mathrm{H}} 3.50\right)$ to $\mathrm{C}-7\left(\delta_{\mathrm{C}} 69.8\right)$. Thus, compound 4 was characterized and named triregelin D.

Compound 5 showed a molecular formula of $\mathrm{C}_{22} \mathrm{H}_{28} \mathrm{O}_{5}$ on the basis of a protonated molecular ion at $m / z 373.1998\left[\mathrm{M}+\mathrm{H}^{+}\left(\right.\right.$calcd $\left.\mathrm{C}_{22} \mathrm{H}_{29} \mathrm{O}_{5}, 373.2010\right)$ in its HRESIMS, 42.0106 amu more than that of triptoquinone B (21) [18]. The 1D NMR spectroscopic data (Tables 1 and 2) of 5 were analogous to those of triptoquinone $B(21)$ [18], except for the presence of an acetyl group $\left(\delta_{\mathrm{H}} 2.03 ; \delta_{\mathrm{C}} 170.8,20.9\right)$. The acetyl group was allocated to C-19, as evidenced from the HMBC correlations from $\mathrm{H}_{2}-19\left(\delta_{\mathrm{H}} 4.56\right.$, $4.08)$ to the carbonyl carbon $\left(\delta_{\mathrm{C}} 170.8\right)$ of the acetyl group. Therefore, compound 5 was determined and named triregelin $\mathrm{E}$.

Compound 6 had a molecular formula of $\mathrm{C}_{20} \mathrm{H}_{28} \mathrm{O}_{2}$ deduced from a protonated molecular ion at $m / z 301.2162\left[\mathrm{M}+\mathrm{H}^{+}\right.$(calcd for $\left.\mathrm{C}_{20} \mathrm{H}_{29} \mathrm{O}_{2}, 301.2162\right)$ in the HRESIMS. IR spectrum of 6 displayed a double bond band at $1626 \mathrm{~cm}^{-1}$, and aromatic ring bands at 1580 and $1424 \mathrm{~cm}^{-1}$. The ${ }^{1} \mathrm{H}$ NMR data (Table 3) showed the characteristic signals for two coupled aromatic protons $\left(\delta_{\mathrm{H}} 7.04\right.$ and $6.09(1 \mathrm{H} \mathrm{each}$, $\mathrm{d}, J=7.8 \mathrm{~Hz}))$, two singlet vinylic protons $\left(\delta_{\mathrm{H}} 4.86\right.$ and 4.77$)$, an oxygenated methylene $\left(\delta_{\mathrm{H}} 3.95\right.$ and $3.70)$, an isopropyl moiety $\left(\delta_{\mathrm{H}} 3.15,1.26\right.$ and 1.25$)$, and a tertiary methyl group $\left(\delta_{\mathrm{H}} 0.99\right)$. The ${ }^{13} \mathrm{C} N \mathrm{NR}$ data (Table 2) displayed resonances for 20 carbons, which were ascribed to a tetrasubstituted benzene ring, an exocyclic double bond, an aliphatic quaternary carbon, three methines, five methylenes (including an oxygenated one) and three methyl groups. The ${ }^{1} \mathrm{H}$ and ${ }^{13} \mathrm{C}$ NMR spectroscopic data of 6 were similar to those of triptobenzene $\mathrm{P}$ [22], an $18(4 \rightarrow 3)$-abeo-abietane diterpene previously isolated from $T$. wilfordii, except for the following two differences. One difference is the replacement of the methoxyl group at $\mathrm{C}-12$ in triptobenzene $\mathrm{P}$ by a hydrogen in 6 , which was supported by ${ }^{1} \mathrm{H}^{-1} \mathrm{H}$ COSY correlation of $\mathrm{H}-11 / \mathrm{H}-12$, and $\mathrm{HMBC}$ correlations from $\mathrm{H}-12\left(\delta_{\mathrm{H}} 7.04\right)$ to $\mathrm{C}-9\left(\delta_{\mathrm{C}} 145.8\right)$ and $\mathrm{C}-15$ $\left(\delta_{C} 26.9\right)$. The other difference is the downfield shift of $C-14\left(\delta_{C} 150.3\right)$ in 6 relative to that $\left(\delta_{C} 123.8\right)$ in triptobenzene $\mathrm{P}$, indicating hydroxylation of $\mathrm{C}-14$ in $\mathbf{6}$. Thus, the planar structure of $\mathbf{6}$ was established as 12-demethoxy-14-hydroxy-triptobenzene $\mathrm{P}$, which was confirmed by the ${ }^{1} \mathrm{H}-{ }^{1} \mathrm{H}$ COSY and HMBC data (Figure 2). The NOE correlations of $\mathrm{H}-5 \alpha / \mathrm{H}_{2}-18$ and $\mathrm{H}_{3}-20 \beta / \mathrm{H}-3$ indicated $\alpha$-orientation of $\mathrm{CH}_{2}-18$ (Figure 3). Thus, compound 6 was defined and named triregelin $\mathrm{F}$.

Compound 7 gave a molecular formula of $\mathrm{C}_{21} \mathrm{H}_{28} \mathrm{O}_{4}$, as established from an $[\mathrm{M}+\mathrm{H}]^{+}$ion at $\mathrm{m} / z$ 345.2055 (calcd for $\mathrm{C}_{21} \mathrm{H}_{29} \mathrm{O}_{4}, 345.2060$ ) in the HRESIMS. IR spectrum of 7 exhibited a carbonyl band at $1703 \mathrm{~cm}^{-1}$, and aromatic ring bands at 1604,1566 and $1455 \mathrm{~cm}^{-1}$. The ${ }^{1} \mathrm{H}$ and ${ }^{13} \mathrm{C}$ NMR spectroscopic data (Tables 2 and 3) of 7 were very similar to those of triptobenzene A (13) [23], except for the absence of two methylene groups and an aromatic proton, and the presence of a double bond $\left(\delta_{\mathrm{H}} 6.82(1 \mathrm{H}, \mathrm{dd}\right.$, $J=10.2,3.0 \mathrm{~Hz}, \mathrm{H}-7) ; 122.1$ and $\left.5.86(1 \mathrm{H}, \mathrm{dd}, J=10.2,3.0 \mathrm{~Hz}, \mathrm{H}-6) ; \delta_{\mathrm{C}} 124.0\right)$, and a methoxyl group $\left(\delta_{\mathrm{H}} 3.80\left(3 \mathrm{H}, \mathrm{s}, \mathrm{OCH}_{3}-12\right) ; \delta_{\mathrm{C}} 55.7\right)$. The double bond was assigned at between $\mathrm{C}-6$ and $\mathrm{C}-7$, which was supported by HMBC correlations from H-6 $\left(\delta_{\mathrm{H}} 5.86\right)$ to C-4 $\left(\delta_{\mathrm{C}} 53.0\right)$ and C-10 $\left(\delta_{\mathrm{C}} 37.7\right)$, and from H-7 $\left(\delta_{\mathrm{H}} 6.82\right)$ to $\mathrm{C}-9\left(\delta_{\mathrm{C}} 145.2\right)$ and $\mathrm{C}-14\left(\delta_{\mathrm{C}} 150.3\right)$. The methoxyl group was located at $\mathrm{C}-12$, as deduced from the HMBC correlation from the methoxyl protons $\left(\delta_{\mathrm{H}} 3.80\right)$ to $\mathrm{C}-12\left(\delta_{\mathrm{C}} 158.3\right)$. The key NOE correlations of $\mathrm{H}-5 \alpha / \mathrm{H}_{3}-18$ and $\mathrm{H}_{3}-20 / \mathrm{H}_{2}-19$ were observed in the NOESY spectrum. Accordingly, compound 7 was elucidated as illustrated in Figure 1, and named triregelin G. 
Table 3. ${ }^{1} \mathrm{H}$ NMR (600 MHz) spectroscopic data for compounds 6-11.

\begin{tabular}{|c|c|c|c|c|c|c|}
\hline \multirow{2}{*}{ Position } & \multicolumn{6}{|c|}{$\delta_{\mathrm{H}}(J$ in $\mathrm{Hz})$} \\
\hline & $6^{a}$ & $7^{a}$ & $8^{a}$ & $9^{a}$ & $10^{a}$ & $11^{b}$ \\
\hline \multirow[b]{2}{*}{1} & $1.63, \operatorname{td}(13.2,4.2)$ & $2.14, \operatorname{td}(13.2,5.4)$ & 2.07, ddd $(16.2,9.6,4.8)$ & $1.50, \operatorname{td}(13.8,3.6)$ & $1.70, \operatorname{td}(13.8,4.2)$ & $1.97, \mathrm{dt}(12.6,3.6)$ \\
\hline & 2.32, dt (13.2, 4.2) & 2.48, ddd $(12.6,6.0,3.0)$ & $3.31, \mathrm{~m}^{\mathrm{c}}$ & 3.34, dt $(13.8,3.6)$ & 2.36, dt $(13.8,3.0)$ & $2.38, \operatorname{td}(13.2,3.6)$ \\
\hline \multirow[b]{2}{*}{2} & $1.43, \mathrm{qd}(13.0,4.2)$ & 2.61, ddd $(15.6,5.4,3.0)$ & 2.54, ddd $(15.6,8.4,7.2)$ & $1.89, \mathrm{~m}^{c}$ & $1.98, \mathrm{~m}$ & $1.87, \mathrm{~m}^{c}$ \\
\hline & $1.92, \mathrm{~m}^{c}$ & 2.83, ddd $(15.6,13.2,6.0)$ & $2.74, \mathrm{~m}^{c}$ & $2.02, \mathrm{~m}$ & $2.04, \mathrm{~m}$ & 2.10, tt $(14.4,3.6)$ \\
\hline 3 & $2.20, \mathrm{~m}^{c}$ & - & - & $3.56, \mathrm{dd}(11.4,3.6)$ & $3.55, \mathrm{dd}(11.4,3.6)$ & $3.68, \mathrm{q}(3.6)$ \\
\hline 5 & $2.17, \mathrm{~d}(12.6)^{c}$ & $2.69, \mathrm{t}(3.0)$ & $2.64, \mathrm{~d}(15.0)^{c}$ & $1.91, \mathrm{dd}(14.4,2.4)^{c}$ & 1.94, dd $(14.4,3.6)$ & $2.22, \mathrm{dd}(12.6,2.4)$ \\
\hline \multirow{2}{*}{6} & $1.81, \mathrm{qd}(12.6,6.0)$ & $5.86, \mathrm{dd}(10.2,3.0)$ & 2.63, d (16.2) & $2.64, \mathrm{dd}(16.8,14.4)$ & 2.67, dd $(18.0,14.4)$ & $1.88, \mathrm{~m}^{c}$ \\
\hline & $1.95, \mathrm{~m}^{c}$ & - & $2.72, \mathrm{~m}^{c}$ & 2.74, dd $(16.8,2.4)$ & 2.80, dd $(18.0,3.6)$ & $1.72, \mathrm{~m}^{\mathrm{c}}$ \\
\hline \multirow[b]{2}{*}{7} & 2.61, ddd $(16.4,12.6,7.2)$ & $6.82, \mathrm{dd}(10.2,3.0)$ & - & - & - & $2.81, \operatorname{ddd}(16.2,11.4,7.8)$ \\
\hline & 2.87, dd $(16.4,6.0)$ & - & - & - & - & $3.13, \mathrm{dd}(16.2,6.6)$ \\
\hline 11 & $6.90, \mathrm{~d}(7.8)$ & $6.34, \mathrm{~s}$ & - & - & $6.74, \mathrm{~d}(7.8)$ & $7.07, \mathrm{~s}$ \\
\hline 12 & $7.04, \mathrm{~d}(7.8)$ & - & $6.83, \mathrm{~s}$ & $6.77, \mathrm{~s}$ & $7.36, \mathrm{~d}(7.8)$ & - \\
\hline 15 & 3.15 , sept (7.2) & 3.44, sept (7.2) & $3.32, \operatorname{sept}(6.6)^{c}$ & 3.30 , sept (6.6) & 3.32 , sept (6.6) & 3.76 , sept (7.2) \\
\hline 16 & $1.26, \mathrm{~d}(7.2)$ & $1.33, \mathrm{~d}(7.2)$ & $1.20, \mathrm{~d}(6.6)$ & $1.18, \mathrm{~d}(6.6)$ & $1.22, \mathrm{~d}(6.6)$ & $1.72, \mathrm{~d}^{\prime}(7.2)^{c}$ \\
\hline 17 & $1.25, \mathrm{~d}(7.2)$ & $1.33, \mathrm{~d}(7.2)$ & $2.21, \mathrm{~d}(6.6)$ & $1.20, \mathrm{~d}(6.6)$ & $1.20, \mathrm{~d}(6.6)$ & $1.68, \mathrm{~d}(7.2)$ \\
\hline \multirow[b]{2}{*}{18} & $3.70, \mathrm{dd}(10.8,6.0)$ & $1.27, \mathrm{~s}$ & $1.35, \mathrm{~s}$ & $1.30, \mathrm{~s}$ & $1.29, \mathrm{~s}$ & $1.27, \mathrm{~s}$ \\
\hline & $3.95, \mathrm{dd}(10.8,6.0)$ & - & - & - & - & - \\
\hline \multirow{2}{*}{19} & $4.77, \mathrm{~s}$ & $3.84, \mathrm{~d}(12.0,4.8)$ & 3.54, d (11.4) & $3.42, \mathrm{dd}(11.4,9.0)$ & 3.50, dd (11.4, 7.8) & $0.96, \mathrm{~s}$ \\
\hline & $4.86, \mathrm{~s}$ & $4.14, \mathrm{~d}(12.0)$ & $4.06, \mathrm{~d}(11.4)$ & $4.35, \mathrm{~d}(11.4)$ & $4.36, \mathrm{~d}(11.4)$ & - \\
\hline 20 & $0.99, \mathrm{~s}$ & $1.21, \mathrm{~s}$ & $1.42, \mathrm{~s}$ & $1.35, \mathrm{~s}$ & $1.19, \mathrm{~s}$ & $1.25, \mathrm{~s}$ \\
\hline $\mathrm{OH}-3$ & - & - & - & - & $2.56, \mathrm{~s}$ & $5.69, \mathrm{~d}(3.6)$ \\
\hline OH-11 & - & - & $4.62, \mathrm{~s}$ & $4.47, \mathrm{~s}$ & - & - \\
\hline OH-12 & - & - & - & - & - & $10.80, \mathrm{~s}$ \\
\hline $\mathrm{OH}-14$ & - & $4.90, \mathrm{~s}$ & $12.79, \mathrm{~s}$ & $12.96, \mathrm{~s}$ & $13.07, \mathrm{~s}$ & - \\
\hline OH-19 & - & $1.77, \mathrm{br} \mathrm{s}$ & $2.96, \mathrm{~s}$ & 2.80, br d $(9.0)$ & 2.83, br d $(7.8)$ & - \\
\hline OMe-12 & - & $3.80, \mathrm{~s}$ & - & - & - & - \\
\hline OMe-14 & - & - & - & - & - & $3.72, \mathrm{~s}$ \\
\hline
\end{tabular}

a Measured in $\mathrm{CDCl}_{3} \cdot{ }^{b}$ Measured in pyridine- $d_{5} \cdot{ }^{c}$ Overlapping signal was assigned from ${ }^{1} \mathrm{H}^{1}{ }^{1} \mathrm{H} C O S Y, \mathrm{HSOC}$, and HMBC experiments. The signals of br, $\mathrm{s}, \mathrm{d}, \mathrm{t}, \mathrm{q}$, sept and $\mathrm{m}$ represent broad, singlet, doublet, triplet, quartet, septet and multiplet splitting patterns of protons, respectively. 
Compound 8 had a molecular formula of $\mathrm{C}_{20} \mathrm{H}_{26} \mathrm{O}_{5}$, according to an $[\mathrm{M}+\mathrm{H}]^{+}$ion at $m / z 347.1840$ $[\mathrm{M}+\mathrm{H}]^{+}$(calcd for $\left.\mathrm{C}_{20} \mathrm{H}_{27} \mathrm{O}_{5}, 347.1853\right)$. The ${ }^{1} \mathrm{H}$ and ${ }^{13} \mathrm{C}$ NMR spectroscopic data (Tables 2 and 3) of 8 were closely related to those of triptobenzene A (13) [23]. However, one of the key differences was the replacement of the methylene at C-7 in triptobenzene A by a keto carbonyl carbon $\left(\delta_{C} 204.3\right)$ in 8 , as evidenced from HMBC correlation from $\mathrm{H}-5\left(\delta_{\mathrm{H}} 2.64\right)$ to C-7. The other difference was the absence of a doublet aromatic proton and the presence of an additional hydroxyl proton $\left(\delta_{\mathrm{H}} 4.62\right)$ together with the downfield shift of $\mathrm{C}-11\left(\delta_{\mathrm{C}} 144.5\right)$ in 8 compared to that in triptobenzene A, which suggested hydroxylation of $\mathrm{C}-11$ in $\mathbf{8}$. Therefore, compound $\mathbf{8}$ was assigned and named triregelin $\mathrm{H}$.

Compound 9 had a molecular formula of $\mathrm{C}_{20} \mathrm{H}_{28} \mathrm{O}_{5}$ based on a protonated molecular ion at $m / z 349.2005[\mathrm{M}+\mathrm{H}]^{+}$(calcd for $\mathrm{C}_{20} \mathrm{H}_{29} \mathrm{O}_{5}, 349.2010$ ), with $2.0161 \mathrm{amu}$ more than that of 8 in the HRESIMS. The ${ }^{13} \mathrm{C}$ NMR spectroscopic data (Table 2) of 9 were closely comparable to those of 8 , except for the absence of the C-3 keto carbonyl in 8, and the presence of an oxygenated methine $\left(\delta_{\mathrm{H}} 3.56(1 \mathrm{H}\right.$, $\left.\mathrm{dd}, J=11.4,3.6 \mathrm{~Hz}, \mathrm{H}-3) ; \delta_{\mathrm{C}} 79.7\right)$ in 9. These suggested that the C-3 keto carbonyl group in 8 was reduced to be a hydroxyl group in 9 . The hydroxyl group at $\mathrm{C}-3$ was $\beta$-oriented, as deduced from the NOESY correlations of $\mathrm{H}-3 / \mathrm{H}-5 \alpha$ and $\mathrm{H}-3 / \mathrm{H}_{3}-18$. Therefore, compound 9 was identified and named triregelin I.

Compound 10 displayed a molecular formula of $\mathrm{C}_{20} \mathrm{H}_{28} \mathrm{O}_{4}$ established by a protonated molecular ion at $m / z 333.2053[\mathrm{M}+\mathrm{H}]^{+}$(calcd for $\mathrm{C}_{20} \mathrm{H}_{29} \mathrm{O}_{4}, 333.2060$ ), revealing 15.9948 amu less than that in 9 in the HRESIMS. The ${ }^{1} \mathrm{H}$ and ${ }^{13} \mathrm{C}$ NMR spectroscopic data (Tables 2 and 3 ) of $\mathbf{1 0}$ were very similar to those of 9 except for the presence of an extra doublet aromatic proton $\left(\delta_{\mathrm{H}} 6.74, \mathrm{H}-11\right)$ and the upfield shift of $\mathrm{C}-11\left(\delta_{\mathrm{C}} 113.6\right)$ relative to that $\left(\delta_{\mathrm{C}} 144.2\right)$ in 9 . These data revealed the dehydroxylation of $\mathrm{C}-11$ in 10, which was further supported by ${ }^{1} \mathrm{H}-{ }^{1} \mathrm{H}$ COSY correlation of $\mathrm{H}-11 / \mathrm{H}-12$, and $\mathrm{HMBC}$ correlations from $\mathrm{H}-11$ to $\mathrm{C}-8\left(\delta_{\mathrm{C}} 114.2\right), \mathrm{C}-10\left(\delta_{\mathrm{C}} 37.5\right)$, and C-13 $\left(\delta_{\mathrm{C}} 134.9\right)$. Hence, compound 10 was elucidated and named triregelin J.

Compound 11 showed a molecular formula of $\mathrm{C}_{21} \mathrm{H}_{32} \mathrm{O}_{3}$, as deduced from a protonated molecular ion at $m / z 333.2426[\mathrm{M}+\mathrm{H}]^{+}$(calcd for $\mathrm{C}_{21} \mathrm{H}_{33} \mathrm{O}_{3}, 333.2424$ ) in the HRESIMS. Comparison of the NMR spectroscopic data (Tables 2 and 3) of $\mathbf{1 1}$ with neotriptonoterpene (14) [24] showed that both compounds were structurally comparable, except for the absence of the C-3 keto carbonyl in neotriptonoterpene (14) and the presence of an extra oxygenated methine $\left(\delta_{\mathrm{H}} 3.68 ; \delta_{\mathrm{C}} 74.8\right)$ in 11. These suggested that the $\mathrm{C}-3$ keto carbonyl group in neotriptonoterpene (14) was reduced to be a hydroxyl group in 11. The C-3 hydroxyl group was $\alpha$-oriented, as inferred from the coupling constant $\left(J_{2,3}=3.6 \mathrm{~Hz}\right)$ and the NOESY correlation between $\mathrm{H}-3$ and $\mathrm{H}_{3}-19$. Accordingly, the compound $\mathbf{1 1}$ was characterized and named triregelin K.

Compound 12, white amorphous power, had a molecular formula of $\mathrm{C}_{20} \mathrm{H}_{30} \mathrm{O}_{2}$, as deduced from an $[\mathrm{M}+\mathrm{H}]^{+}$ion at $m / z 303.2322$ (calcd for $\mathrm{C}_{20} \mathrm{H}_{31} \mathrm{O}_{2}, 303.2319$ ) in the HRESIMS. IR spectrum of 12 exhibited a strong carbonyl band at $1710 \mathrm{~cm}^{-1}$. The ${ }^{1} \mathrm{H}$ NMR spectrum (Table 1) exhibited the characteristic signals for a vinylic group $\left(\delta_{\mathrm{H}} 4.99\right.$ and 4.87$)$, an oxygenated methylene $\left(\delta_{\mathrm{H}} 3.68\right.$ and 3.44), a hydroxyl group $\left(\delta_{\mathrm{H}} 1.09\right)$, and two tertiary methyls $\left(\delta_{\mathrm{H}} 0.98\right.$ and 0.85$)$. The ${ }^{13} \mathrm{C} \mathrm{NMR}$ and DEPT spectra (Table 2) showed 20 carbon signals including a carbonyl group, an exocyclic double bond, three quaternary carbons, there methines, nine methylenes (including an oxygenated one) and two methyl groups. All the above NMR data indicated that 12 was a kaurane type diterpenoid, and structurally similar to (-)-ent-kaur-16-en-19-ol [25-27]. The distinct difference was that the C-12 methylene in (-)-ent-kaur-16-en-19-ol was oxidized to be a keto carbonyl group in 12, as deduced from the downfield shift of C-12 $\left(\delta_{\mathrm{C}} 211.5\right)$, and the HMBC correlations from $\mathrm{H}-9\left(\delta_{\mathrm{C}} 1.58\right)$ and $\mathrm{H}_{2}-14$ $\left(\delta_{\mathrm{H}} 2.40,1.51\right)$ to $\mathrm{C}-12$. Finally, the planar structure of 12 was confirmed on the basis of the ${ }^{1} \mathrm{H}-{ }^{1} \mathrm{H}$ COSY and HMBC experiments (Figure 2). In the NOESY spectrum, the correlations of $\mathrm{H}_{3}-20 / \mathrm{H}_{2}-19$ and $\mathrm{H}_{3}-20 / \mathrm{H}_{2}-14$ indicated that these protons were in the same face. In the same way, the other key NOE cross peaks of H-5/H-9 and H-9/ $\mathrm{H}_{2}-15$ were also observed (Figure 3), suggesting H-5, H-9, and $\mathrm{H}_{2}-15$ were in the other face. However, 12 displayed a positive specific rotation $\left([\alpha]_{\mathrm{D}}^{21}+50.86(c 0.50\right.$, $\mathrm{MeOH})$ ) in contrast to the negative one reported for (-)-ent-kaur-16-en-19-ol [27]. ECD curves for 
the two possible stereo-structures $(4 R, 5 S, 8 S, 9 R, 10 S, 13 R-\mathbf{1 2}$ and $4 S, 5 R, 8 R, 9 S, 10 R, 13 S-12)$ were, therefore, calculated to determine the absolute configuration of 12. As illustrated in Figure $4 B$, the calculated profile of $4 R, 5 S, 8 S, 9 R, 10 S$, and $13 R-\mathbf{1 2}$ were in good agreement with the experimental $C D$ spectrum of 12. Therefore, compound $\mathbf{1 2}$ was identified and named triregelin $\mathrm{L}$.

The compounds 3, 6, 7, and 9 were also selected to calculate their ECD data in order to further confirm their absolute configurations. As the results, their experimental CD spectra showed similar CD pattern to the calculated ones of $(4 S, 5 R, 7 R, 10 S)-3,(3 R, 5 S, 10 S)-6,(4 S, 5 R, 10 S)-7$, and $(3 S, 4 S, 5 R$, 10S)-9, respectively (Figure S1). The HRMS, UV, IR, NMR and CD spectra (Figures S2-S121) of twelve new compounds were shown in supplementary materials.

In addition, eleven known abietanes were also isolated from the stems of T. regelii, including triptobenzene A (13) [23], neotriptonoterpene (14) [24], triptobenzene M (15) [28], wilforol F (16) [29], triptobenzene J (17) [30], triptobenzene B (18) [23], abieta-8, 11, 13-triene-14, 19-diol (19) [31], triptoquinone A (20), triptoquinone B (21), triptoquinone D (22) and triptoquinone F (23) [18]. These compounds were identified by comparison of their spectroscopic (1D NMR and specific rotation) and HRMS data with those reported in the literature. Compound $\mathbf{1}$ is the first abietane type diterpene with an $18 \rightarrow 1$ lactone ring. The discovery of the above twelve new diterpenes contributed to the chemical diversity of natural terpenoids.

Cytotoxic effects of seventeen diterpenes $(\mathbf{2}, 7-11,13-23)$ were evaluated against three cancer cell lines of A2780, HepG2 and MCF-7. As the results show (Table 4), compound 9 displayed cytotoxicity against A2780, HepG2, and MCF-7 cells with $\mathrm{IC}_{50}$ values of 5.88, 11.74, and $46.40 \mu \mathrm{M}$, respectively. Compound 11 showed solely cytotoxic effect on MCF-7 cell with an $\mathrm{IC}_{50}$ value of $26.70 \mu \mathrm{M}$. Compound 14 exhibited weak cytotoxic activity on A2780, HepG2, and MCF-7 cells with IC 50 values of $65.80,35.45$, and $64.80 \mu \mathrm{M}$, respectively.

Table 4. Cytotoxic effects of diterpenes on three cancer cell lines of A2780, HepG2, and MCF-7.

\begin{tabular}{cccc}
\hline Compounds * & $\mathrm{IC}_{\mathbf{5 0}}(\boldsymbol{\mu M})$ against A2780 & $\mathrm{IC}_{\mathbf{5 0}}(\boldsymbol{\mu M})$ against HepG2 & $\mathrm{IC}_{\mathbf{5 0}}(\boldsymbol{\mu M})$ against MCF-7 \\
\hline $\mathbf{9}$ & $5.88 \pm 2.22$ & $11.74 \pm 1.92$ & $46.40 \pm 3.54$ \\
$\mathbf{1 1}$ & $>100$ & $>100$ & $26.70 \pm 5.57$ \\
$\mathbf{1 4}$ & $65.80 \pm 21.53$ & $35.45 \pm 8.23$ & $64.80 \pm 24.90$ \\
taxol & $0.006 \pm 0.001$ & $0.003 \pm 0.0002$ & $0.005 \pm 0.001$ \\
\hline
\end{tabular}

* Seventeen compounds $(\mathbf{2}, \mathbf{7 - 1 1}, \mathbf{1 3 - 2 3})$ were evaluated for cytotoxic effects against three cancer cell lines; $\mathrm{IC}_{50}$ values for other tested compounds were larger than $100 \mu \mathrm{M}$ on three cancer cells.

\section{Materials and Methods}

\subsection{General Experimental Procedures}

Optical rotations were obtained using a Rudolph Research Analytical Autopol I automatic polarimeter (Rudolph Research Analytical, Hackettstown, NJ, USA). IR spectra were measured on an Agilent Cary 600 series FT-IR spectrometer (KBr) (Agilent, Santa Clara, CA, USA). Ultraviolet (UV) spectra were recorded on a Beckman Coulter DU ${ }^{\circledR} 800$ spectrophotometer (Beckman Coulter, Fullerton, CA, USA). HRMS spectra were carried out on an Agilent 6230 electrospray ionization (ESI) time-of-flight (TOF) mass spectrometer (Agilent, Santa Clara, CA, USA). Nuclear magnetic resonance (NMR) spectra were measured on a Bruker Ascend $600 \mathrm{NMR}$ spectrometer at $600 \mathrm{MHz}$ for ${ }^{1} \mathrm{H}$ NMR and $150 \mathrm{MHz}$ for ${ }^{13} \mathrm{C}$ NMR (Bruker, Zurich, Switzerland). Chemical shifts were expressed in $\delta(\mathrm{ppm})$ with tetramethylsilane (TMS) as an internal reference, and coupling constants $(J)$ were reported in hertz (Hz). Circular dichroism spectra were measured on a Jasco J1500 CD spectrometer (Jasco Corporation, Tokyo, Japan). Medium pressure liquid chromatography (MPLC) was conducted on a Sepacore Flash Chromatography System (Buchi, Flawil, Switzerland) by employing a flash column (460 mm $\times 36 \mathrm{~mm}$, i.d., Buchi) packed with Bondapak Waters ODS (40-63 $\mu \mathrm{m}$, Waters, Milford, MA, USA). Preparative high performance liquid chromatography (HPLC) was carried out on a Waters 
Xbridge Prep $\mathrm{C}_{8}$ column $(10 \mathrm{~mm} \times 250 \mathrm{~mm}, 5 \mu \mathrm{m})$ by utilizing a Waters liquid chromatography system equipped with 1525 Binary HPLC Pump and 2489 UV/Visible detector (Waters, Milford, MA, USA). Semi-preparative HPLC was done on a Waters Xbridge Prep $C_{18}$ column $(10 \mathrm{~mm} \times 250 \mathrm{~mm}, 5 \mu \mathrm{m})$ by using an Agilent 1100 liquid chromatography system coupled with a quaternary pump and a diode array detector (DAD) (Agilent, Santa Clara, CA, USA). Column chromatography was conducted on silica gel (40-60 $\mu \mathrm{m}$, Grace, Columbia, MD, USA) and Bondapak Waters ODS (40-63 $\mu \mathrm{m}$, Waters). Thin layer chromatographies (TLCs) were performed on pre-coated silica gel $60 \mathrm{~F}_{254}$ plates and TLC silica gel 60 RP-18 $\mathrm{F}_{254 \mathrm{~S}}$ plates ( $200 \mu \mathrm{m}$ thick, Merck KGaA, Darmstadt, Germany), which were used to monitor fractions. Spots on the TLC were visualized by UV light $(254 \mathrm{~nm})$ or heating after spraying with $5 \% \mathrm{H}_{2} \mathrm{SO}_{4}$ in ethanol.

\subsection{Plant Material}

The stems of T. regelii used in this study were collected from Changbai Mountain in Jilin province, China, in October 2012. The plant was authenticated by Liang Xu, Liaoning University of Traditional Chinese Medicine (Dalian, China). A voucher specimen (No. MUST-TR201210) has been deposited at State Key Laboratory of Quality Research in Chinese Medicine, Macau University of Science and Technology.

\subsection{Extraction and Isolation}

The air-dried stems of T. regelii $(8.0 \mathrm{~kg})$ were powdered, and extracted three times with methanol $(64 \mathrm{~L})$ under ultrasonic-assisted extraction at room temperature for $1 \mathrm{~h}$. The methanol extract was evaporated under reduced pressure to yield a dark brown residue, which was then suspended in $\mathrm{H}_{2} \mathrm{O}$, and successively partitioned with $n$-hexane, ethyl acetate (EtOAc) and $n$-butanol. Then, the EtOAc-soluble extract ( $150.0 \mathrm{~g}$ ) was fractionated over a silica gel column using a gradient system of petroleum ether (PE)-acetone (100:0-35:65, $v / v$ ) to provide thirteen fractions (Fr.1-Fr.13). Fraction 5 was chromatographed over an ODS column using a gradient system of $\mathrm{MeOH}-\mathrm{H}_{2} \mathrm{O}(50: 50-100: 0, v / v)$ to yield eight fractions (Fr.5-1-Fr.5-8). Fractions 5-2 $(110.0 \mathrm{mg})$ and 5-4 $(130.0 \mathrm{mg})$ were further separated on silica gel columns eluted with PE-EtOAc (95:5-55:45, v/v) to afford compounds 22 (15.0 mg) and 23 $(30.0 \mathrm{mg})$, respectively. Similarly, fraction $7(5.0 \mathrm{~g})$ was subjected to an ODS column with a gradient system of $\mathrm{MeOH}-\mathrm{H}_{2} \mathrm{O}(40: 60-90: 10, v / v)$ to give nine fractions (Fr.7-1-Fr.7-9). Compounds 20 (50.0 mg) and 21 (30.0 mg) were obtained by silica gel columns separation using PE-EtOAc (90:10-30:70, v/v) as eluting solvents from fractions 7-2 $(150.0 \mathrm{mg})$ and 7-4 $(100.0 \mathrm{mg})$, respectively. Fraction $8(5.4 \mathrm{~g})$ was subjected to an ODS column using a gradient system of $\mathrm{MeOH}-\mathrm{H}_{2} \mathrm{O}(35: 65-80: 20, v / v)$ to afford ten fractions (Fr.8-1-Fr.8-10). The fraction 8-3 (2.5 g) was fractionated over a silica gel column, with a gradient elution by PE-EtOAc (90:10-63:35, v/v), to produce seven fractions (Fr.8-3-1-Fr.8-3-7). Fraction 8-3-4 (40.5 mg) was purified by semi-preparative HPLC using $\mathrm{CH}_{3} \mathrm{CN}-\mathrm{H}_{2} \mathrm{O}(52: 48, v / v)$ as mobile phase to afford compounds $5(0.6 \mathrm{mg}), \mathbf{1 2}(0.7 \mathrm{mg})$ and $\mathbf{1 8}(1.0 \mathrm{mg})$. Fraction 8-3-5 (200.6 mg) was subjected to semi-preparative HPLC using $\mathrm{CH}_{3} \mathrm{CN}-\mathrm{H}_{2} \mathrm{O}(58: 42, v / v)$ as solvent system to give compounds 6 (1.9 mg) and $11(2.0 \mathrm{mg})$, as well as subfraction 8-3-5-2. Compounds 14 (1.6 mg) and 19 (1.0 mg) were obtained by preparative HPLC with an isocratic elution of $\mathrm{CH}_{3} \mathrm{CN}_{-} \mathrm{H}_{2} \mathrm{O}$ (55:45, $v / v$ ) from the subfraction 8-3-5-2 $(65.7 \mathrm{mg})$. Fraction $11(5.5 \mathrm{~g})$ was chromatographed over an ODS column, eluted with $\mathrm{MeOH}-\mathrm{H}_{2} \mathrm{O}$ (30:70-100:0, v/v), to afford sixteen fractions (Fr.11-1-Fr.11-16). Compound $3(5.0 \mathrm{mg})$ was isolated by preparative HPLC eluting with a $\mathrm{MeOH}-\mathrm{H}_{2} \mathrm{O}(35: 65, v / v)$ solvent system from fraction 11-4 (26.9 mg). Fraction 11-6 (49.5 mg) was separated by semi-preparative HPLC using $\mathrm{CH}_{3} \mathrm{CN}-\mathrm{H}_{2} \mathrm{O}(35: 65, \mathrm{v} / \mathrm{v}$ ) as mobile phase to yield compound 2 (5.0 mg). Fraction 11-7 (261.1 mg) was subjected to a silica gel column with a gradient elution of PE-EtOAc (20:80-10:90, $v / v)$ and purified by semi-preparative HPLC using $\mathrm{CH}_{3} \mathrm{CN}-\mathrm{H}_{2} \mathrm{O}(40: 60, v / v)$ as eluting solvent to afford compounds $8(1.2 \mathrm{mg}), 4(2.0 \mathrm{mg}), \mathbf{1 3}(1.6 \mathrm{mg})$ and fraction 11-7-3. Compounds 7 (0.6 mg) and $16(3.1 \mathrm{mg})$ were purified by semi-preparative $\mathrm{HPLC}$ with a $\mathrm{CH}_{3} \mathrm{CN}-\mathrm{H}_{2} \mathrm{O}(42: 58, v / v)$ solvent system from fraction 11-7-3 $(56.9 \mathrm{mg})$. Fraction $11-8(284.3 \mathrm{mg})$ was isolated by preparative HPLC 
using $\mathrm{MeOH}-\mathrm{H}_{2} \mathrm{O}(46: 54, v / v)$ as mobile phase to yield compound $1(0.59 \mathrm{mg})$ and five fractions (Fr.11-8-1-Fr.11-8-5). Fraction 11-8-2 (42.5 mg) was subjected to semi-preparative HPLC with a $\mathrm{CH}_{3} \mathrm{CN}-\mathrm{H}_{2} \mathrm{O}(47: 53, v / v)$ solvent system to give compound $15(2.0 \mathrm{mg})$. Fraction 11-8-3 (30.3 mg) was isolated by semi-preparative HPLC using $\mathrm{CH}_{3} \mathrm{CN}-\mathrm{H}_{2} \mathrm{O}(45: 55, v / v)$ as eluting solvent to yield compounds $\mathbf{1 0}(1.6 \mathrm{mg})$ and $\mathbf{1 7}(2.1 \mathrm{mg})$. Fraction $12(9.0 \mathrm{~g})$ was separated by MPLC using a gradient system of $\mathrm{MeOH}-\mathrm{H}_{2} \mathrm{O}$ (5:95-100:0, $50 \mathrm{~mL} / \mathrm{min}$ ) to obtain six fractions (Fr.12-1-Fr.12-6). Fraction 12-5 was chromatographed over a silica gel column using $\mathrm{CHCl}_{3}-\mathrm{MeOH}(100: 0-90: 10, v / v)$ as solvent system, and then purified by semi-preparative HPLC using $\mathrm{CH}_{3} \mathrm{CN}-\mathrm{H}_{2} \mathrm{O}(39: 61, v / v)$ as mobile phase to give compound $\mathbf{9}(1.2 \mathrm{mg})$.

\subsection{Structural Characterization}

Triregelin A (1): yellow amorphous powder; $[\alpha]_{\mathrm{D}}^{21}+3.8(c 0.50, \mathrm{MeOH}) ; \mathrm{IR}(\mathrm{KBr}) v_{\max }: 3444,2925$, $2854,1732,1601,1455,1377,1260,1167,1086,1013,957,893,803,756,667 \mathrm{~cm}^{-1}$; UV (MeOH) $\lambda_{\max }$ $(\log \varepsilon) 260(2.35) \mathrm{nm} ; \mathrm{CD}\left(c 2.92 \times 10^{-3} \mathrm{~mol} / \mathrm{L}, \mathrm{MeOH}\right) \lambda_{\max }(\Delta \varepsilon) 225(-1.22), 311(+0.16) ;{ }^{1} \mathrm{H}$ NMR $\left(\mathrm{CDCl}_{3}, 600 \mathrm{MHz}\right)$ and ${ }^{13} \mathrm{C} \mathrm{NMR}\left(\mathrm{CDCl}_{3}, 150 \mathrm{MHz}\right)$ data, see Tables 1 and 2; HRESIMS $\mathrm{m} / z 343.1546$ $[\mathrm{M}+\mathrm{H}]^{+}$(calcd for $\mathrm{C}_{20} \mathrm{H}_{23} \mathrm{O}_{5}, 343.1540$ ).

Triregelin B (2): yellow amorphous powder; $[\alpha]_{\mathrm{D}}^{21}+75.5$ (c 1.00, MeOH); IR (KBr) $v_{\max }$ : 3421, 2970, 2937, 2881, 1688, 1649, 1436, 1375, 1248, 1104, 1030, 977, 905, 798, 659, $599 \mathrm{~cm}^{-1}$; UV (MeOH) $\lambda_{\max }$ $(\log \varepsilon) 258(3.17) \mathrm{nm} ; \mathrm{CD}\left(c 1.46 \times 10^{-3} \mathrm{~mol} / \mathrm{L}, \mathrm{MeOH}\right) \lambda_{\max }(\Delta \varepsilon) 269(+7.24), 355(+0.35), 476(-0.54)$; ${ }^{1} \mathrm{H} \mathrm{NMR}\left(\mathrm{CDCl}_{3}, 600 \mathrm{MHz}\right)$ and ${ }^{13} \mathrm{C} \mathrm{NMR}\left(\mathrm{CDCl}_{3}, 150 \mathrm{MHz}\right)$ data, see Tables 1 and $2 ; \mathrm{HRESIMS} \mathrm{m} / \mathrm{z}$ $343.1560[\mathrm{M}-\mathrm{H}]^{-}$(calcd for $\left.\mathrm{C}_{20} \mathrm{H}_{23} \mathrm{O}_{5}, 343.1551\right)$.

Triregelin C (3): yellow, amorphous powder; $[\alpha]_{\mathrm{D}}^{21}-34.0$ (c 1.00, MeOH); IR (KBr) $v_{\max }$ : 3437, 2966, 2936, 2876, 1700, 1650, 1463, 1430, 1383, 1294, 1235, 1165,1107, 1044, 974, 933, 900, 813, $741 \mathrm{~cm}^{-1}$; $\mathrm{UV}(\mathrm{MeOH}) \lambda_{\max }(\log \varepsilon) 256(3.42) \mathrm{nm} ; \mathrm{CD}\left(c 1.45 \times 10^{-3} \mathrm{~mol} / \mathrm{L}, \mathrm{MeOH}\right) \lambda_{\max }(\Delta \varepsilon) 283(+2.21)$, $359(-0.25), 478(-0.32) ;{ }^{1} \mathrm{H} \mathrm{NMR}\left(\mathrm{CDCl}_{3}, 600 \mathrm{MHz}\right)$ and ${ }^{13} \mathrm{C} \mathrm{NMR}\left(\mathrm{CDCl}_{3}, 150 \mathrm{MHz}\right.$,) data, see Tables 1 and 2; HRESIMS $m / z 347.1866[\mathrm{M}+\mathrm{H}]^{+}$(calcd for $\mathrm{C}_{20} \mathrm{H}_{27} \mathrm{O}_{5}, 347.1853$ ).

Triregelin D (4): yellow, amorphous powder; $[\alpha]_{\mathrm{D}}^{21}-9.3$ (c 1.00, MeOH); IR (KBr) $v_{\text {max }}: 3435,2964$, 2932, 2877, 1688, 1652, 1606, 1462, 1426, 1383, 1293, 1234, 1192, 1085, 1039, 910, $856 \mathrm{~cm}^{-1}$; UV (MeOH) $\lambda_{\max }(\log \varepsilon) 255(3.19) \mathrm{nm} ; \mathrm{CD}\left(c 1.39 \times 10^{-3} \mathrm{~mol} / \mathrm{L}, \mathrm{MeOH}\right) \lambda_{\max }(\Delta \varepsilon) 271$ (+3.05), $357(-0.22)$, $481(-0.61) ;{ }^{1} \mathrm{H}$ NMR $\left(\mathrm{CDCl}_{3}, 600 \mathrm{MHz}\right)$ and ${ }^{13} \mathrm{C} \mathrm{NMR}\left(\mathrm{CDCl}_{3}, 150 \mathrm{MHz}\right)$ data, see Tables 1 and 2; HRESIMS $m / z 361.2008[\mathrm{M}+\mathrm{H}]^{+}$(calcd for $\mathrm{C}_{21} \mathrm{H}_{29} \mathrm{O}_{5}, 361.2010$ ).

Triregelin E (5): yellow, amorphous powder; $[\alpha]_{\mathrm{D}}^{21}+17.0(c 0.50, \mathrm{MeOH}) ; \mathrm{IR}(\mathrm{KBr}) v_{\max }: 3455$, 2962, 2930, 2874, 1744, 1713, 1650, 1604, 1464, 1384, 1294, 1233, 1104, 1042, 906, 802, 757, 666, $603 \mathrm{~cm}^{-1}$; $\mathrm{UV}(\mathrm{MeOH}) \lambda_{\max }(\log \varepsilon) 257(2.75) \mathrm{nm} ; \mathrm{CD}\left(c 1.34 \times 10^{-3} \mathrm{~mol} / \mathrm{L}, \mathrm{MeOH}\right) \lambda_{\max }(\Delta \varepsilon) 261(+3.35)$, 349 (+0.33), $474(-0.30) ;{ }^{1} \mathrm{H}$ NMR $\left(\mathrm{CDCl}_{3}, 600 \mathrm{MHz}\right)$ and ${ }^{13} \mathrm{C} \mathrm{NMR}\left(\mathrm{CDCl}_{3}, 150 \mathrm{MHz}\right)$ data, see Tables 1 and 2; HRESIMS $m / z 373.1998[\mathrm{M}+\mathrm{H}]^{+}$(calcd for $\mathrm{C}_{22} \mathrm{H}_{29} \mathrm{O}_{5}, 373.2010$ ).

Triregelin F (6): yellow, amorphous powder; $[\alpha]_{\mathrm{D}}^{21}+169.3(c 1.00, \mathrm{MeOH}) ; \mathrm{IR}(\mathrm{KBr}) v_{\max }$ : 3437, 2964, 2872, 1626, 1424, 1250, 1160, 1115, 1059, 896, 815, $705 \mathrm{~cm}^{-1}$; UV (MeOH) $\lambda_{\max }(\log \varepsilon) 223$ (3.03), 270 (2.35) nm; CD (c $\left.1.67 \times 10^{-3} \mathrm{~mol} / \mathrm{L}, \mathrm{MeOH}\right) \lambda_{\max }(\Delta \varepsilon) 209$ (+5.51), 217 (sh) (+3.41), 265 (+1.02); ${ }^{1} \mathrm{H} \mathrm{NMR}\left(\mathrm{CDCl}_{3}, 600 \mathrm{MHz}\right)$ and ${ }^{13} \mathrm{C} \mathrm{NMR}\left(\mathrm{CDCl}_{3}, 150 \mathrm{MHz}\right)$ data, see Tables 2 and 3 ; HRESIMS $\mathrm{m} / \mathrm{z}$ $301.2162[\mathrm{M}+\mathrm{H}]^{+}$(calcd for $\left.\mathrm{C}_{20} \mathrm{H}_{29} \mathrm{O}_{2}, 301.2162\right)$.

Triregelin G (7): yellow, amorphous powder; $[\alpha]_{\mathrm{D}}^{21}-46.9$ (c 0.50, MeOH); IR (KBr) $v_{\max }$ : 3382, 2958, 2929, 2872, 1703, 1604, 1566, 1455, 1417, 1378, 1312, 1261, 1224, 1137, 1107, 1056, 802, 756, $667 \mathrm{~cm}^{-1}$; $\mathrm{UV}(\mathrm{MeOH}) \lambda_{\max }(\log \varepsilon) 233$ (3.23), 279 (2.37), $312(2.45) \mathrm{nm} ; \mathrm{CD}\left(c 1.45 \times 10^{-3} \mathrm{~mol} / \mathrm{L}, \mathrm{MeOH}\right) \lambda_{\max }$ $(\Delta \varepsilon) 239(-2.50), 286(+1.08), 311(-1.02), 392(+0.31) ;{ }^{1} \mathrm{H} \mathrm{NMR}\left(\mathrm{CDCl}_{3}, 600 \mathrm{MHz}\right)$ and ${ }^{13} \mathrm{C} \mathrm{NMR}\left(\mathrm{CDCl}_{3}\right.$, $150 \mathrm{MHz}$ ) data, see Tables 2 and 3; HRESIMS $m / z 345.2055[\mathrm{M}+\mathrm{H}]^{+}$(calcd for $\mathrm{C}_{21} \mathrm{H}_{29} \mathrm{O}_{4}, 345.2060$ ).

Triregelin H (8): yellow, amorphous powder; $[\alpha]_{\mathrm{D}}^{21}+56.4\left(c\right.$ 1.00, MeOH); IR (KBr) $v_{\max }$ : 3398, 2961, 2926, 2872, 1697, 1624, 1429, 1382, 1349, 1301, 1233, 1162, 1107, 1040, 964, 894, 801, $754 \mathrm{~cm}^{-1}$; $\mathrm{UV}(\mathrm{MeOH}) \lambda_{\max }(\log \varepsilon) 238(2.82), 270(2.38) \mathrm{nm} ; \mathrm{CD}\left(c 1.45 \times 10^{-3} \mathrm{~mol} / \mathrm{L}, \mathrm{MeOH}\right) \lambda_{\max }(\Delta \varepsilon) 233$ 
(+2.77), $270(-0.27), 310(-1.08), 377(+1.25) ;{ }^{1} \mathrm{H} \mathrm{NMR}\left(\mathrm{CDCl}_{3}, 600 \mathrm{MHz}\right)$ and ${ }^{13} \mathrm{C} \mathrm{NMR}\left(\mathrm{CDCl}_{3}\right.$, $150 \mathrm{MHz}$ ) data, see Tables 2 and 3; HRESIMS $m / z 347.1840[\mathrm{M}+\mathrm{H}]^{+}$(calcd for $\mathrm{C}_{20} \mathrm{H}_{27} \mathrm{O}_{5}, 347.1853$ ).

Triregelin I (9): white, amorphous powder; $[\alpha]_{\mathrm{D}}^{21}+29.4$ (c 0.50, MeOH); IR (KBr) $v_{\text {max }}$ : 3396, 2959, 2924, 2854, 1714, 1592, 1428, 1348, 1260, 1168, 1114, 1028, 970, 800, 755, $709 \mathrm{~cm}^{-1}$; UV (MeOH) $\lambda_{\max }$ $(\log \varepsilon) 235$ (3.32), $270(3.22), 380(2.95) \mathrm{nm} ; \mathrm{CD}\left(c 1.44 \times 10^{-3} \mathrm{~mol} / \mathrm{L}, \mathrm{MeOH}\right) \lambda_{\max }(\Delta \varepsilon) 206(+2.23)$, $235(+0.88), 271(-0.65), 311(-0.61), 375(+0.96) ;{ }^{1} \mathrm{H} \mathrm{NMR}\left(\mathrm{CDCl}_{3}, 600 \mathrm{MHz}\right)$ and ${ }^{13} \mathrm{C} \mathrm{NMR}\left(\mathrm{CDCl}_{3}\right.$, $150 \mathrm{MHz}$ ) data, see Tables 2 and 3; HRESIMS $m / z 349.2005[\mathrm{M}+\mathrm{H}]^{+}$(calcd for $\mathrm{C}_{20} \mathrm{H}_{29} \mathrm{O}_{5}, 349.2010$ ).

Triregelin J (10): white, amorphous powder; $[\alpha]_{\mathrm{D}}^{21}+1.4$ (c 1.00, MeOH); IR (KBr) $v_{\max }$ : 3364, 2962, 2937, 2870, 1622, 1558, 1455, 1427, 1381, 1347, 1251, 1212, 1160, 1113, 1080, 1037, 981, 914, 821, 757, 711, 663, $582 \mathrm{~cm}^{-1}$; UV (MeOH) $\lambda_{\max }(\log \varepsilon) 216$ (3.40), 266 (2.33), $343(2.42) \mathrm{nm} ; \mathrm{CD}\left(c 1.51 \times 10^{-3} \mathrm{~mol} / \mathrm{L}\right.$, $\mathrm{MeOH}) \lambda_{\max }(\Delta \varepsilon) 218(+1.82), 230(+1.34), 266(-3.14), 333(+1.23), 346(+1.71) ;{ }^{1} \mathrm{H} \mathrm{NMR}\left(\mathrm{CDCl}_{3}\right.$, $600 \mathrm{MHz})$ and ${ }^{13} \mathrm{C}$ NMR $\left(\mathrm{CDCl}_{3}, 150 \mathrm{MHz}\right)$ data, see Tables 2 and 3; HRESIMS $\mathrm{m} / z 333.2053[\mathrm{M}+\mathrm{H}]^{+}$ (calcd for $\mathrm{C}_{20} \mathrm{H}_{29} \mathrm{O}_{4}, 333.2060$ ).

Triregelin K (11): white, amorphous powder; $[\alpha]_{\mathrm{D}}^{21}+28.1(c 0.25, \mathrm{MeOH}) ; \mathrm{IR}(\mathrm{KBr}) v_{\max }$ : 3396, 3210, 2926, 2865, 1737, 1607, 1581, 1441, 1412, 1373, 1331, 1308, 1268, 1206, 1101, 1041, 942, 926, 857, 800, 756, 695, $660 \mathrm{~cm}^{-1}$; UV (MeOH) $\lambda_{\max }(\log \varepsilon) 227(2.82), 283(2.36) \mathrm{nm} ; \mathrm{CD}\left(c 1.51 \times 10^{-3} \mathrm{~mol} / \mathrm{L}\right.$, $\mathrm{MeOH}) \lambda_{\max }(\Delta \varepsilon) 228(+0.97) ;{ }^{1} \mathrm{H}$ NMR (pyridine- $d_{5}, 600 \mathrm{MHz}$ ) and ${ }^{13} \mathrm{C}$ NMR (pyridine- $d_{5}, 150 \mathrm{MHz}$ ) data, see Tables 2 and 3; HRESIMS $m / z 333.2426[\mathrm{M}+\mathrm{H}]^{+}$(calcd for $\mathrm{C}_{21} \mathrm{H}_{33} \mathrm{O}_{3}, 333.2424$ ).

Triregelin L (12): white, amorphous powder; $[\alpha]_{\mathrm{D}}^{21}+50.86(c 0.50, \mathrm{MeOH}) ; \mathrm{IR}(\mathrm{KBr}) v_{\max }: 3475$, 3072, 2961, 2924, 2867, 1710, 1655, 1607, 1510, 1445, 1415, 1369, 1261, 1089, 1028, 882, 801, 701, $665 \mathrm{~cm}^{-1}$; $\mathrm{UV}(\mathrm{MeOH}) \lambda_{\max }(\log \varepsilon) 203(3.15) \mathrm{nm} ; \mathrm{CD}\left(c 1.66 \times 10^{-1} \mathrm{~mol} / \mathrm{L}, \mathrm{MeOH}\right) \lambda_{\max }(\Delta \varepsilon) 203(-24.65)$, 295 (+6.40); ${ }^{1} \mathrm{H}$ NMR $\left(\mathrm{CDCl}_{3}, 600 \mathrm{MHz}\right)$ and ${ }^{13} \mathrm{C}$ NMR $\left(\mathrm{CDCl}_{3}, 150 \mathrm{MHz}\right)$ data, see Tables 1 and 2; HRESIMS $m / z 303.2322[\mathrm{M}+\mathrm{H}]^{+}$(calcd for $\mathrm{C}_{20} \mathrm{H}_{31} \mathrm{O}_{2}, 303.2319$ ).

\subsection{Calculation Methods of Electronic Circular Dichroism (ECD) Spectra}

The Gaussian 09 software package [32] was used to conduct all of the ECD calculations. The molecule geometries of molecules were firstly optimized at the level of B3LYP/6-31G $(d, p)$ and the output geometries were subsequently employed to perform ECD calculations using time-dependent density functional theory (TDDFT) with the method of B3LYP/DGDZVP $[20,21]$ since this method usually offers desirable outcomes [33]. The model of polarizable continuum was utilized to simulate the solvation effect in the calculations of circular dichroism. The experimental condition was simulated by using methanol as the solvent. The absolute configurations of all compounds were defined by comparing the calculated ECD curves with the experimental spectra.

\subsection{Cytotoxicity of Diterpenes against Three Cancer Cell Lines}

The A2780 (ovarian carcinoma) cell line was obtained from the KeyGEN biotech (Nanjing, China). HepG2 (hepatocellular carcinoma) and MCF-7 (human breast cancer) cell lines were purchased from the American Type Culture Collection. All of the cell lines were cultured in Dulbecco's modified Eagle medium (DMEM) (Invitrogen) supplemented with 10\% $(v / v)$ heat-inactivated fetal bovine serum (FBS) (Invitrogen), $100 \mathrm{U} / \mathrm{mL}$ penicillin, and $100 \mu \mathrm{g} / \mathrm{mL}$ streptomycin (Invitrogen) in a humidified atmosphere of $5 \% \mathrm{CO}_{2} / 95 \%$ air at $37{ }^{\circ} \mathrm{C}$. Briefly, cells were seeded in 96-well plates in triplicate at a density of $2 \times 10^{3}$ cells / well $(100 \mu \mathrm{L})$ and cultured at $37^{\circ} \mathrm{C}$ in a $5 \% \mathrm{CO}_{2}$ humidified atmosphere for $24 \mathrm{~h}$. Then, the cells were treated with fresh culture medium containing various concentrations of tested compounds and incubated at $37{ }^{\circ} \mathrm{C}$ under a humidified atmosphere of $5 \% \mathrm{CO}_{2} / 95 \%$ air for another $72 \mathrm{~h}$. After that, the supernatant in each well was discarded and the cells were washed by phosphate-buffered saline (PBS) to avoid the possible effect of culture medium and tested compounds on the following MTT (3-(4,5-dimethylthiazol-2-yl)-2,5-diphenyltetrazolium bromide) assay. Subsequently, cells were incubated for $4 \mathrm{~h}$ at $37^{\circ} \mathrm{C}$ in culture medium containing a final concentration of $0.5 \mathrm{mg} / \mathrm{mL}$ MTT $(100 \mu \mathrm{L})$. The formed formazan crystals were dissolved in DMSO $(100 \mu \mathrm{L})$ after removing the supernatant in each well. A microplate reader (Infinite $200 \mathrm{PRO}$, 
Tecan, Männedorf, Switzerland) was employed to determine the absorbance of each well at $570 \mathrm{~nm}$. GraphPad Prism 6 software (Prism 6.0, GraphPad Software, Inc., La Jolla, CA, USA) was used to calculate the $\mathrm{IC}_{50}$ values (concentration that suppresses $50 \%$ of cell growth) of all tested compounds. All assays were performed in triplicate in three independent experiments. Data was expressed as mean $\pm \operatorname{SD}(n=3)$.

\section{Conclusions}

To sum up, 23 diterpenoids were isolated from the Chinese herbal medicine T. regelii, including eleven new abietane, and one new kaurane, diterpenes. Importantly, triregelin A (1) represents the first abietane diterpene bearing an $18 \rightarrow 1$ lactone ring. Triregelin I (9) exhibited significant cytotoxic effects on A2780 and HepG2 cancer cells with $\mathrm{IC}_{50}$ values of $5.88 \mu \mathrm{M}$ and $11.74 \mu \mathrm{M}$, respectively, and was found inactive against MCF-7 cancer cells. Triregelin K (11) displayed a weak cytotoxic effect on MCF-7 cell with an $\mathrm{IC}_{50}$ value of $26.70 \mu \mathrm{M}$.

Supplementary Materials: Supplementary materials can be found at www.mdpi.com/1422-0067/18/1/147/s1.

Acknowledgments: This research was supported financially by Macao Science and Technology Development Fund, Macao Special Administrative Region (Grant No. 056/2013/A2, and 063/2011/A3).

Author Contributions: Li-Ping Bai and Zhi-Hong Jiang conceived and designed the experiments; Dongsheng Fan and Zhiyuan Zheng performed the experiments; Shuangyan Zhou and Xiaojun Yao conducted the calculations of ECD. Dongsheng Fan and Zhiyuan Zheng analyzed the data; Guo-Yuan Zhu guided the structural elucidations. Ming-Rong Yang performed the measurement of all IR spectra; Li-Ping Bai and Dongsheng Fan wrote the paper; Zhi-Hong Jiang revised the manuscript.

Conflicts of Interest: The authors declare no conflict of interest.

\section{Abbreviations}

$\begin{array}{ll}\text { HRESIMS } & \text { High resolution electrospray ionization mass spectrometry } \\ \text { CD } & \text { Circular dichroism } \\ \text { UV } & \text { Ultraviolet visible } \\ \text { IR } & \text { Infrared } \\ \text { NMR } & \text { Nuclear magnetic resonance } \\ \text { DEPT } & \text { Distortionless enhancement by polarization transfer } \\ \text { HSQC } & \text { Heteronuclear single quantum coherence } \\ \text { HMBC } & \text { Heteronuclear multiple bond correlation } \\ { }^{1} \mathrm{H}-{ }^{1} \mathrm{H} \text { COSY } & \text { Proton-proton correlation spectroscopy } \\ \text { NOESY } & \text { Nuclear Overhauser effect spectroscopy }\end{array}$

\section{References}

1. Rodríguez, B. ${ }^{1} \mathrm{H}$ and ${ }^{13} \mathrm{C}$ NMR spectral assignments of some natural abietane diterpenoids. Magn. Reson. Chem. 2003, 41, 741-746. [CrossRef]

2. González, M.A. Aromatic abietane diterpenoids: Their biological activity and synthesis. Nat. Prod. Rep. 2015, 32, 684-704. [CrossRef] [PubMed]

3. Yang, X.W.; Feng, L.; Li, S.M.; Liu, X.H.; Li, Y.L.; Wu, L.; Shen, Y.H.; Tian, J.M.; Zhang, X.; Liu, X.R. Isolation, structure, and bioactivities of abiesadines A-Y, 25 new diterpenes from Abies georgei orr. Bioorg. Med. Chem. 2010, 18, 744-754. [CrossRef] [PubMed]

4. Burmistrova, O.; Simões, M.F.T.; Rijo, P.; Quintana, J.; Bermejo, J.; Estévez, F. Antiproliferative activity of abietane diterpenoids against human tumor cells. J. Nat. Prod. 2013, 76, 1413-1423. [CrossRef] [PubMed]

5. Kafil, V.; Eskandani, M.; Omidi, Y.; Nazemiyeh, H.; Barar, J. Abietane diterpenoid of Salvia sahendica boiss and buhse potently inhibits MCF-7 breast carcinoma cells by suppression of the PI3K/AKT pathway. RSC Adv. 2015, 5, 18041-18050. [CrossRef]

6. Zhang, G.J.; Li, Y.H.; Jiang, J.D.; Yu, S.S.; Qu, J.; Ma, S.G.; Liu, Y.B.; Yu, D.Q. Anti-coxsackie virus b diterpenes from the roots of Illicium jiadifengpi. Tetrahedron 2013, 69, 1017-1023. [CrossRef]

7. Zhang, G.J.; Li, Y.H.; Jiang, J.D.; Yu, S.S.; Wang, X.J.; Zhuang, P.Y.; Zhang, Y.; Qu, J.; Ma, S.G.; Li, Y. Diterpenes and sesquiterpenes with anti-coxsackie virus B3 activity from the stems of Illicium jiadifengpi. Tetrahedron 2014, 70, 4494-4499. [CrossRef] 
8. González, M.A.; Zaragozá, R.N.J. Semisynthesis of the antiviral abietane diterpenoid jiadifenoic acid C from callitrisic acid (4-epidehydroabietic acid) isolated from sandarac resin. J. Nat. Prod. 2014, 77, 2114-2117. [CrossRef] [PubMed]

9. Wang, Y.D.; Zhang, G.J.; Qu, J.; Li, Y.H.; Jiang, J.D.; Liu, Y.B.; Ma, S.G.; Li, Y.; Lv, H.N.; Yu, S.S. Diterpenoids and sesquiterpenoids from the roots of Illicium majus. J. Nat. Prod. 2013, 76, 1976-1983. [CrossRef] [PubMed]

10. Pferschy-Wenzig, E.M.; Kunert, O.; Presser, A.; Bauer, R. In vitro anti-inflammatory activity of larch (Larix decidua L.) sawdust. J. Agric. Food Chem. 2008, 56, 11688-11693. [CrossRef] [PubMed]

11. Efferth, T.; Kahl, S.; Paulus, K.; Adams, M.; Rauh, R.; Boechzelt, H.; Hao, X.; Kaina, B.; Bauer, R. Phytochemistry and pharmacogenomics of natural products derived from traditional chinese medicine and chinese materia medica with activity against tumor cells. Mol. Cancer Ther. 2008, 7, 152-161. [CrossRef] [PubMed]

12. Johnson, J.J. Carnosol: A promising anti-cancer and anti-inflammatory agent. Cancer Lett. 2011, 305, 1-7. [CrossRef] [PubMed]

13. Zhou, Z.L.; Yang, Y.X.; Ding, J.; Li, Y.C.; Miao, Z.H. Triptolide: Structural modifications, structure-activity relationships, bioactivities, clinical development and mechanisms. Nat. Prod. Rep. 2012, 29, 457-475. [CrossRef]

14. Zhou, X.; Wang, Y.; Lee, W.Y.; Or, P.M.; Wan, D.C.; Kwan, Y.W.; Yeung, J.H. Miltirone is a dual inhibitor of P-glycoprotein and cell growth in doxorubicin-resistant hepG2 cells. J. Nat. Prod. 2015, 78, 2266-2275. [CrossRef] [PubMed]

15. Fan, D.; Zhu, G.Y.; Chen, M.; Xie, L.M.; Jiang, Z.H.; Xu, L.; Bai, L.P. Dihydro- $\beta$-agarofuran sesquiterpene polyesters isolated from the stems of Tripterygium regelii. Fitoterapia 2016, 112, 1-8. [CrossRef] [PubMed]

16. Fan, D.; Parhira, S.; Zhu, G.Y.; Jiang, Z.H.; Bai, L.P. Triterpenoids from the stems of Tripterygium regelii. Fitoterapia 2016, 113, 69-73. [CrossRef] [PubMed]

17. Fan, D.; Zhu, G.Y.; Li, T.; Jiang, Z.H.; Bai, L.P. Dimacrolide sesquiterpene pyridine alkaloids from the stems of Tripterygium regelii. Molecules 2016, 21, 1146. [CrossRef] [PubMed]

18. Shishido, K.; Nakano, K.; Wariishi, N.; Tateishi, H.; Omodani, T.; Shibuya, M.; Goto, K.; Ono, Y.; Takaishi, Y. Tripterygium wilfordii var. Regelii which are interleukin-1 inhibitors. Phytochemistry 1994, 35, 731-737. [CrossRef]

19. Xu, Y.; Ma, Y.; Zhou, L.; Sun, H. Abietane quinones from Rabdosia lophanthoides. Phytochemistry 1988, 27, 3681-3682. [CrossRef]

20. Becke, A.D. A new mixing of hartree-Fock and local density-functional theories. J. Chem. Phys. 1993, 98, 1372-1377. [CrossRef]

21. Godbout, N.; Salahub, D.R.; Andzelm, J.; Wimmer, E. Optimization of gaussian-type basis sets for local spin density functional calculations. Part I. Boron through neon, optimization technique and validation. Can. J. Chem. 1992, 70, 560-571. [CrossRef]

22. Shen, Q.; Takaishi, Y.; Zhang, Y.W.; Duan, H.Q. Immunosuppressive terpenoids from Tripterygium wilfordii. Chin. Chem. Lett. 2008, 19, 453-456. [CrossRef]

23. Takaishi, Y.; Wariishi, N.; Tateishi, H.; Kawazoe, K.; Miyagi, K.; Li, K.; Duan, H. Phenolic diterpenes from Tripterygium wilfordii var. Regelii. Phytochemistry 1997, 45, 979-984. [CrossRef]

24. Zhou, B.; Zhu, D.; Deng, F.; Huang, C.; Kutney, J.P.; Roberts, M. Studies on new components and stereochemistry of diterpenoids from Trypterygium wilfordii. Planta Med. 1988, 54, 330-332. [CrossRef] [PubMed]

25. Pacheco, A.G.; Machado de Oliveira, P.; Piló-Veloso, D.; Flávio de Carvalho Alcântara, A. ${ }^{13}$ C-NMR data of diterpenes isolated from Aristolochia species. Molecules 2009, 14, 1245-1262. [CrossRef] [PubMed]

26. Gonzalez, A.G.; Fraga, B.M.; Hernandez, M.G.; Hanson, J.R. The ${ }^{13} \mathrm{C}$ NMR spectra of some ent-18-hydroxykaur-16-enes. Phytochemistry 1981, 20, 846-847. [CrossRef]

27. Bohlmann, F.; Rao, N. Natürlich vorkommende Terpen-Derivate, XXI. Über die Inhaltsstoffe von Anona squamosa L. Chem. Ber. 1973, 106, 841-844. [CrossRef]

28. Duan, H.; Takaishi, Y.; Momota, H.; Ohmoto, Y.; Taki, T.; Jia, Y.; Li, D. Immunosuppressive diterpenoids from Tripterygium wilfordii. J. Nat. Prod. 1999, 62, 1522-1525. [CrossRef] [PubMed]

29. Morota, T.; Qin, W.Z.; Takagi, K.; Xu, L.H.; Maruno, M.; Yang, B.H. Diterpenoids from Tripterigium wilfordii. Phytochemistry 1995, 40, 865-870. [CrossRef] 
30. Duan, H.; Kawazoe, K.; Bando, M.; Kido, M.; Takaishi, Y. Di-and triterpenoids from Tripterygium hypoglaucum. Phytochemistry 1997, 46, 535-543. [CrossRef]

31. Zhou, W.; Xie, H.; Wu, P.; Wei, X. Abietane diterpenoids from Isodon lophanthoides var. Graciliflorus and their cytotoxicity. Food Chem. 2013, 136, 1110-1116. [CrossRef] [PubMed]

32. Gaussian 09; Revision A. 1; Gaussian Inc.: Wallingford, CT, USA, 2009.

33. Berova, N.; di Bari, L.; Pescitelli, G. Application of electronic circular dichroism in configurational and conformational analysis of organic compounds. Chem. Soc. Rev. 2007, 36, 914-931. [CrossRef] [PubMed]

(C) 2017 by the authors; licensee MDPI, Basel, Switzerland. This article is an open access article distributed under the terms and conditions of the Creative Commons Attribution (CC-BY) license (http:/ / creativecommons.org/licenses/by/4.0/). 